\title{
Synthetic Studies toward the Construction of the cis-Decalin Portion of Superstolides A and B. Application of a Sequential Double Michael Reaction and an Anionic Oxy-Cope Rearrangement
}

\author{
Zhengmao Hua, Wensheng Yu, Mei Su, and Zhendong Jin* \\ Division of Medicinal and Natural Products Chemistry, College of Pharmacy, \\ The University of Iowa, Iowa City, IA 52242
}

Supporting Information

Materials and methods

Experimental section

Copies of NMR spectrum $\left({ }^{1} \mathrm{H}\right.$ and $\left.{ }^{13} \mathrm{C}\right)$ 


\section{Materials and methods}

Unless stated otherwise, reactions were performed in flame-dried glassware under a positive pressure of argon using freshly distilled solvent. Tetrahydrofuran (THF) and diethyl ether were distilled from sodium/benzophenone before use. Dichloromethane, benzene were distilled from $\mathrm{CaH}_{2}$. Methanol was bought from Aldrich (anhydrous methanol, 99.8\%). Thin-layer chromatography (TLC) was performed using Merck silica gel $60 \mathrm{~F}_{254}$ glass plates. Visualization of the developed chromatography was performed by UV absorbance (254 $\mathrm{nm}$ ) and visualizing solutions. The commonly employed in TLC visualizing components were: anisaldehyde solution and potassium permanganate solution. Column chromatography was performed using Silicycle silica gel (230-400 mesh). ${ }^{1} \mathrm{H}-\mathrm{NMR}$ and ${ }^{13} \mathrm{C}-\mathrm{NMR}$ spectra were recorded with a Bruker Advance300 (300 MHz), Bruker DRX400 (400 MHz) or Bruker Advance600 (600 MHz) instruments.

\section{Experimental section}

Compound 24
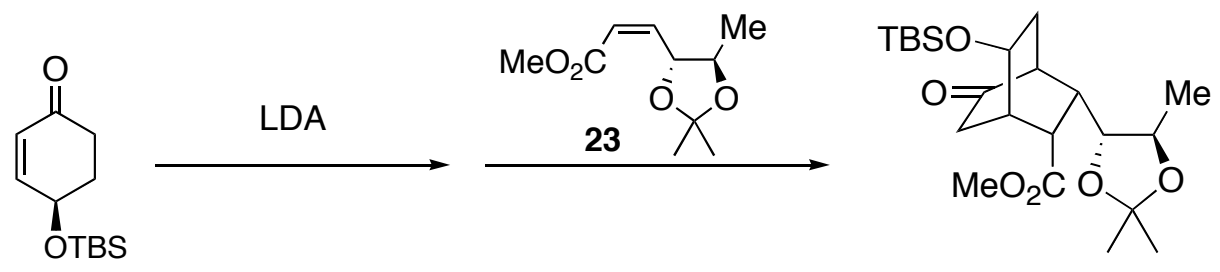

11

24

A $50 \mathrm{~mL}$ round bottom flask was charged with diisopropylamine $(303 \mathrm{mg}, 2.98$ $\mathrm{mmol})$ in $10 \mathrm{~mL}$ THF. The solution was cooled to $-40{ }^{\circ} \mathrm{C}$ and $n$-BuLi $(2.35 \mathrm{M}$ in hexanes, $1.16 \mathrm{~mL}, 2.73 \mathrm{mmol}$ ) was added dropwise over 5 minutes. The solution was allowed to warm up to $-20{ }^{\circ} \mathrm{C}$ in $20 \mathrm{~min}$ and then cooled to $-78^{\circ} \mathrm{C}$. To this solution was added 11 (562 mg, $2.48 \mathrm{mmol}$ ) in $10 \mathrm{~mL}$ THF. The solution was allowed to warm up to $-40{ }^{\circ} \mathrm{C}$ in $30 \mathrm{~min}$ and then cooled to $-78^{\circ} \mathrm{C} .23(447 \mathrm{mg}, 2.23 \mathrm{mmol})$ in $2 \mathrm{~mL}$ THF was added to the flask via a cannula. The reaction was warmed up to $0{ }^{\circ} \mathrm{C}$ in 1 hour and stirred at $0{ }^{\circ} \mathrm{C}$ for 15 hours. The reaction was quenched with $15 \mathrm{~mL}$ saturated aqueous sodium bicarbonate and diluted with $20 \mathrm{~mL}$ EtOAc. The organic layer was separated and the water layer was extracted by EtOAc $(15 \mathrm{~mL})$ for three times. The combined organic layer 
was washed with brine, dried over anhydrous $\mathrm{Na}_{2} \mathrm{SO}_{4}$ and concentrated in vacuo. The crude mixture was purified by flash column chromatography to provide desired product 24 (400 mg, 42\%) as a white solid and recover $136 \mathrm{mg}$ starting material 23.

\section{Compound 25}
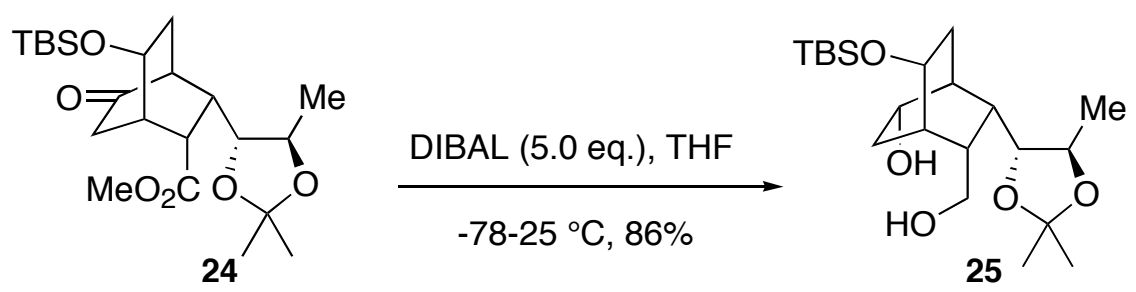

To a solution of $24(635 \mathrm{mg}, 1.49 \mathrm{mmol})$ in THF (15 mL) was added DIBAL $(1.0 \mathrm{M}$ in hexanes, $7.44 \mathrm{~mL}, 7.44 \mathrm{mmol})$ at $-78^{\circ} \mathrm{C}$. The reaction was allowed to warm up to $0{ }^{\circ} \mathrm{C}$ gradually in 3.5 hours, stirred at $0{ }^{\circ} \mathrm{C}$ for 2 hours, and then warmed up to $25^{\circ} \mathrm{C}$ gradually in 2 hours. The reaction was quenched with ethyl acetate $(1 \mathrm{~mL})$. Saturated aqueous sodium potassium tartrate $(8 \mathrm{~mL})$ was added and the reaction mixture was stirred at room temperature for 30 minutes. The organic layer was separated and the water layer was extracted by $\mathrm{CH}_{2} \mathrm{Cl}_{2}(15 \mathrm{~mL})$ for three times. The combined organic layer was washed with brine and dried over anhydrous $\mathrm{Na}_{2} \mathrm{SO}_{4}$. The solvent was removed and the crude product was purified with silica gel column chromatography to afford 25 (640 mg, $86 \%)$ as a white solid.

\section{Compound 25a}
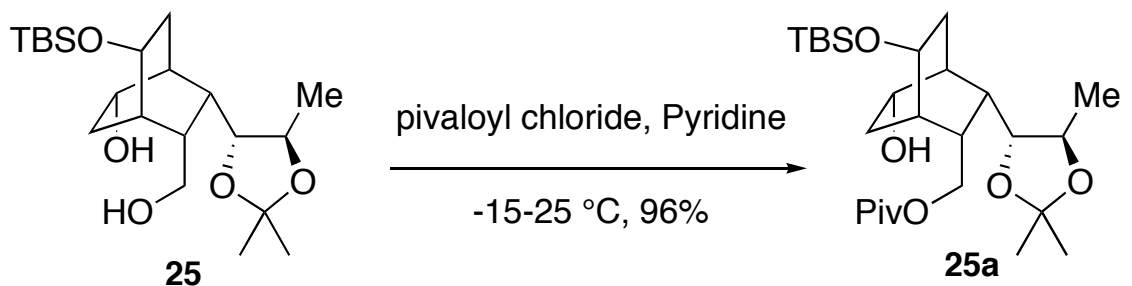

To a solution of 25 (825 $\mathrm{mg}, 2.06 \mathrm{mmol})$ in pyridine $(8 \mathrm{~mL})$ was added pivaloyl chloride (323 mg, $2.67 \mathrm{mmol}$ ) at $-15^{\circ} \mathrm{C}$. The reaction was allowed to warm up to $25^{\circ} \mathrm{C}$ gradually in 3 hours, and was stirred at $25^{\circ} \mathrm{C}$ for 5 hours. Pyridine was removed under vacuum and the reaction mixture was diluted with $\mathrm{CHCl}_{3}(20 \mathrm{~mL})$, washed by $5 \%$ 
aqueous $\mathrm{NaHCO}_{3}(10 \mathrm{~mL})$. The organic layer was separated and the aqueous layer was extracted by $\mathrm{CHCl}_{3}(15 \mathrm{~mL})$ three times. The combined organic layer was washed with brine and dried over anhydrous $\mathrm{Na}_{2} \mathrm{SO}_{4}$. The solvent was removed and the product was purified with flash column chromatography to afford $\mathbf{2 5 a}(959 \mathrm{mg}, 96 \%)$ as a white solid.

\section{Compound 26}
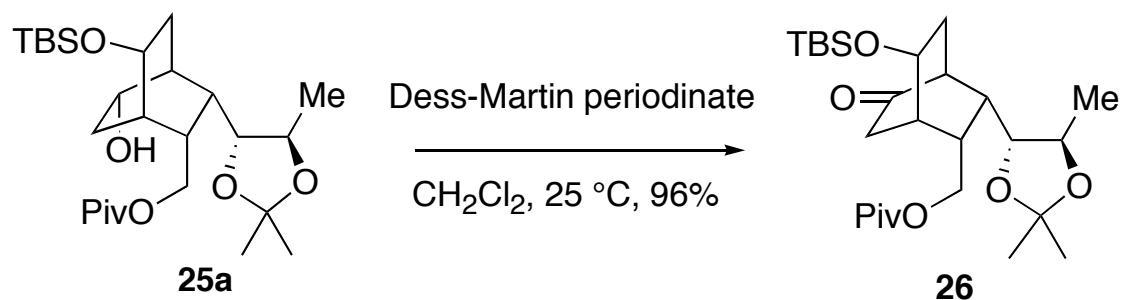

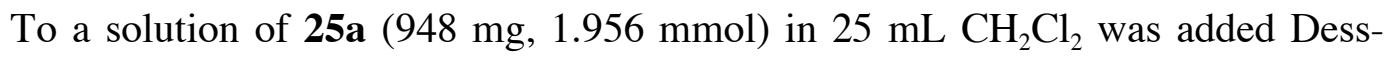
Martin reagent $(912 \mathrm{mg}, 2.15 \mathrm{mmol})$. The reaction was stirred at $25{ }^{\circ} \mathrm{C}$ for 1 hour, and was quenched by the addition of $5 \mathrm{~mL} 20 \% \mathrm{NaS}_{2} \mathrm{O}_{3}$ at $0{ }^{\circ} \mathrm{C}$. The organic layer was separated and the aqueous layer was extracted with $\mathrm{CH}_{2} \mathrm{Cl}_{2}(8 \mathrm{~mL})$ three times. The combined organic layer was washed with brine and dried over anhydrous $\mathrm{Na}_{2} \mathrm{SO}_{4}$. The crude mixture was concentrated and purified by flash column chromatography to provide 26 (906.5 $\mathrm{mg}, 96 \%)$ as a white solid.

\section{Compound 26a}
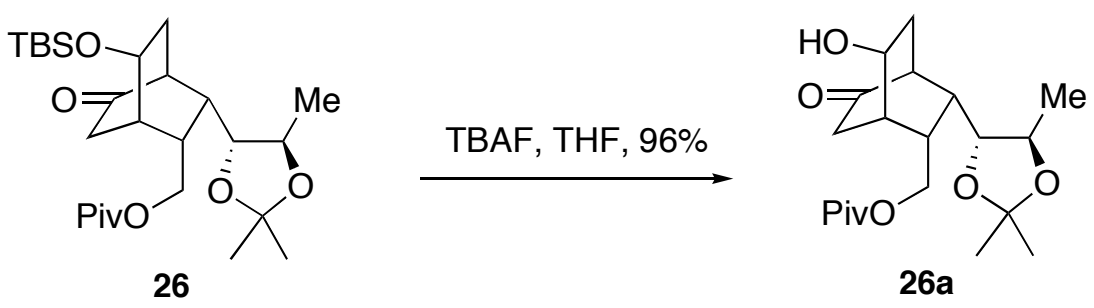

To a solution of $26(1.10 \mathrm{~g}, 2.28 \mathrm{mmol})$ in THF $(7 \mathrm{~mL})$ was added TBAF (1.0 M in THF, $2.96 \mathrm{~mL}, 2.96 \mathrm{mmol}$ ). The solution was stirred at $25^{\circ} \mathrm{C}$ for 3 hours and was monitored by thin layer chromatography (Hexanes:EtOAc=1:2 ). The reaction mixture was concentrated and purified by flash column chromatography to provide 26a (806 mg, 96\%) as colorless oil. 


\section{Compound 26b}

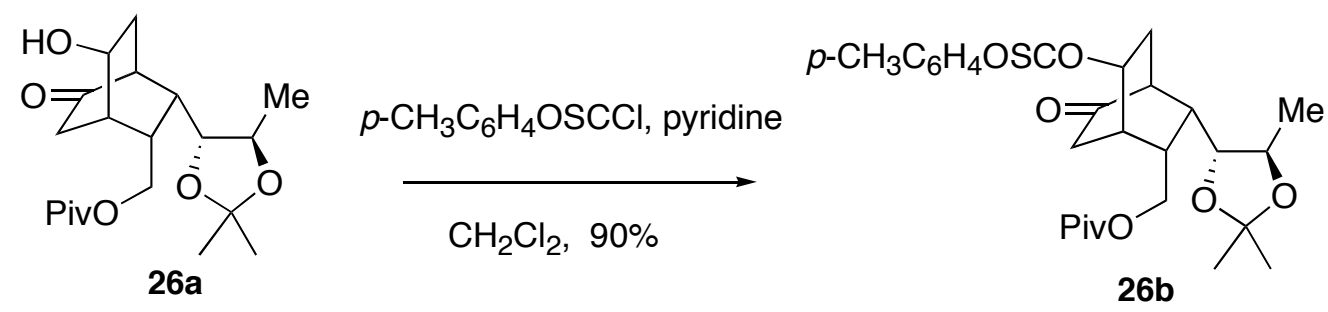

To a solution of $\mathbf{2 6 a}$ (505 $\mathrm{mg}, 1.37 \mathrm{mmol}$ ) in $10 \mathrm{~mL} \mathrm{CH}_{2} \mathrm{Cl}_{2}$ was added pyridine (433 mg, $5.48 \mathrm{mmol}$ ) and p-tolyl chlorothionoformate (767 mg, $4.11 \mathrm{mmol}$ ). The reaction was stirred at $25^{\circ} \mathrm{C}$ for 6 hours. Pyridine was removed under reduced pressure and 10 mL saturated aqueous $\mathrm{NaHCO}_{3}$ was added. The crude mixture was extracted with $\mathrm{CH}_{2} \mathrm{Cl}_{2}$ (15 mL, 3 times). The combined organic layer was washed by brine and dried over anhydrous $\mathrm{Na}_{2} \mathrm{SO}_{4}$. The crude mixture was concentrated and purified by flash column chromatography to provide $\mathbf{2 6 b}$ (640 $\mathrm{mg}, 90 \%)$ as a white solid.

\section{Compound 27a}

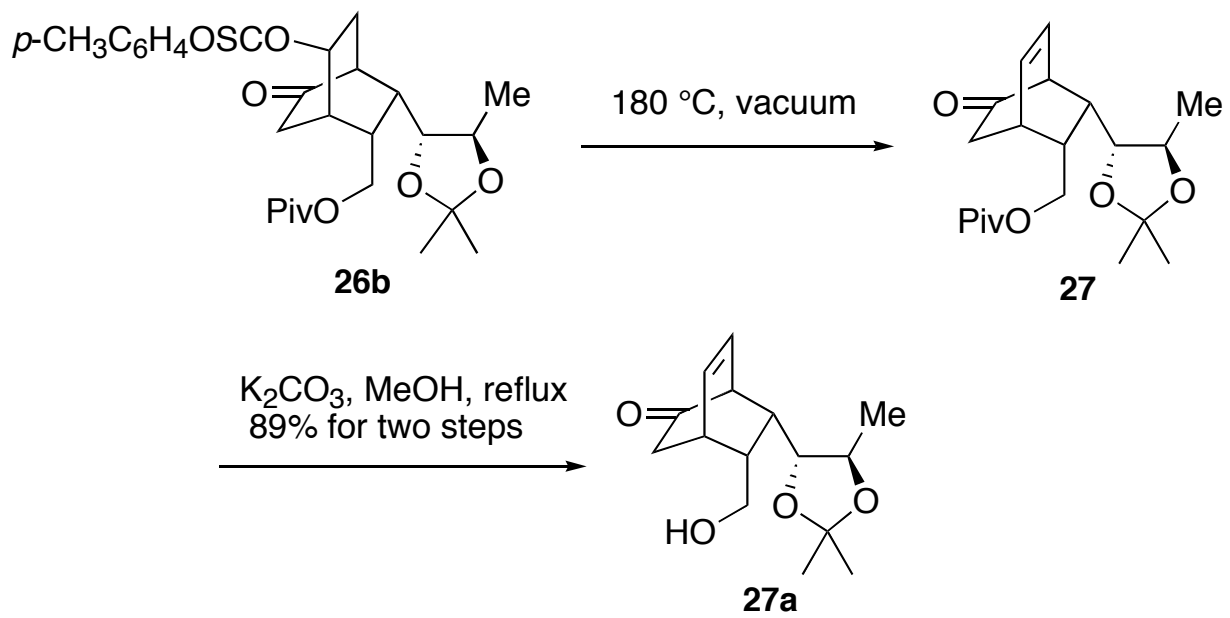

A $25 \mathrm{~mL}$ round bottom flask containing $\mathbf{2 6 b}(654 \mathrm{mg}, 1.26 \mathrm{mmol})$ was heated to $180{ }^{\circ} \mathrm{C}$ under vacuum for 2 hours. The crude product 27 was used for the next reaction without further purification.

To the flask containing crude product 27 was added $10 \mathrm{~mL} \mathrm{MeOH}$ and anhydrous $\mathrm{K}_{2} \mathrm{CO}_{3}(30 \mathrm{mg}, 0.217 \mathrm{mmol})$. The reaction was heated at reflux for 24 hours and monitored by thin layer chromatography (Hexanes: Ethyl Acetate=1:1). The reaction 
mixture was concentrated and purified by flash column chromatography to provide $\mathbf{2 7 a}$ (302 mg, 89\% for two steps) as a white solid.

\section{Compound 28}
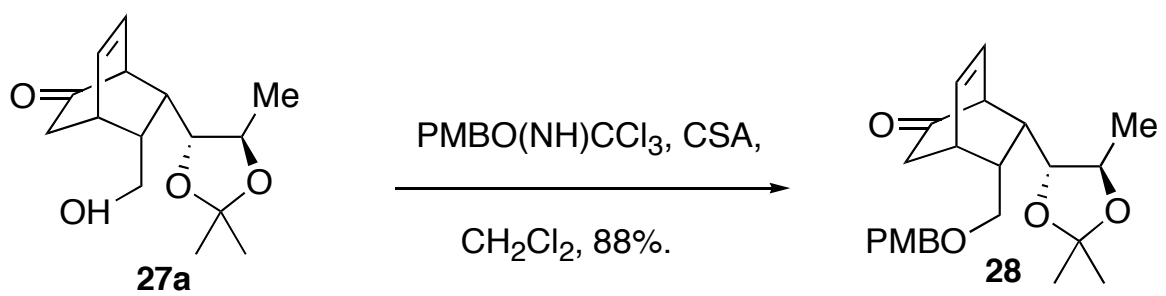

To a $10 \mathrm{~mL}$ flask containing 27a (100 mg, $0.375 \mathrm{mmol})$ was added a solution of 0.45M PMBO(NH)CCl $(1 \mathrm{~mL}, 0.45 \mathrm{mmol})$ in $\mathrm{CH}_{2} \mathrm{Cl}_{2}$. The reaction was stirred at $25^{\circ} \mathrm{C}$ for 20 hours, heated to $45^{\circ} \mathrm{C}$ for 30 minutes, and was then quenched by addition of $1 \mathrm{~mL}$ $5 \%$ aqueous $\mathrm{NaOH}$. The reaction mixture was extracted by $\mathrm{CH}_{2} \mathrm{Cl}_{2}(10 \mathrm{~mL}, 3$ times). The combined organic layer was washed with brine and dried over anhydrous $\mathrm{Na}_{2} \mathrm{SO}_{4}$. The crude mixture was concentrated under vacuum and purified by flash column chromatography to provide compound 28 (128 mg, 88\%) as colorless oil.

\section{Compound 26c}

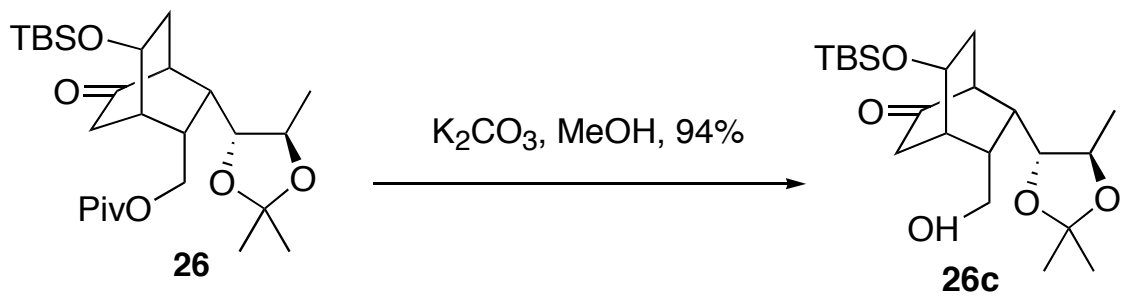

To a $50 \mathrm{~mL}$ round bottom flask containing $26(1.01 \mathrm{~g}, 2.09 \mathrm{mmol})$ in $15 \mathrm{~mL}$ $\mathrm{MeOH}$ was added anhydrous $\mathrm{K}_{2} \mathrm{CO}_{3}(57.8 \mathrm{mg}, 0.418 \mathrm{mmol})$. The reaction was heated at reflux for 24 hours and monitored by thin layer chromatography (Hexanes: Ethyl Acetate=2:1). The crude mixture was concentrated and purified by flash column chromatography to provide $\mathbf{2 6 c}$ (783 $\mathrm{mg}, 94 \%$ ) as colorless oil. 


\section{Compound 32}

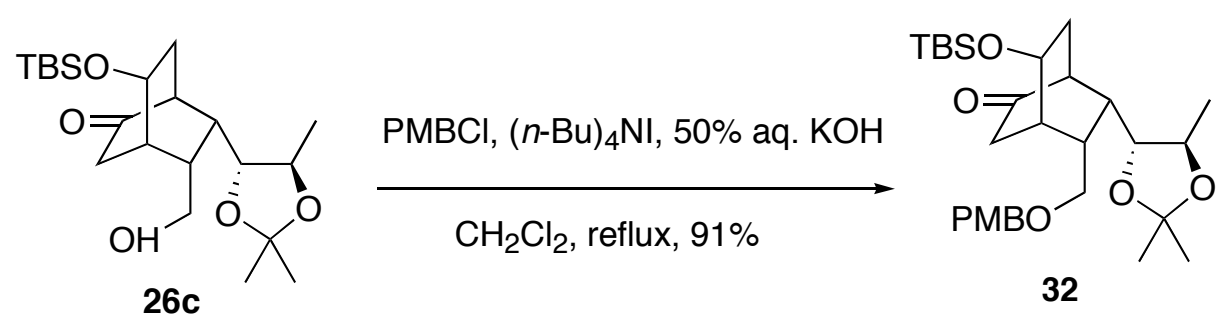

To a $100 \mathrm{~mL}$ round bottom flask containing $26 \mathrm{c}(401 \mathrm{mg}, 1.01 \mathrm{mmol})$ in $20 \mathrm{~mL}$ $\mathrm{CH}_{2} \mathrm{Cl}_{2}$, was added $50 \%$ aqueous $\mathrm{KOH}(20 \mathrm{~mL}), \mathrm{PMBCl}(0.633 \mathrm{~g}, 4.04 \mathrm{mmol})$ and $(n-$ $\mathrm{Bu})_{4} \mathrm{NI}(112 \mathrm{mg}, 3.03 \mathrm{mmol})$. The reaction was heated at reflux for 4 hours. The organic layer was separated and the aqueous layer was extracted by $\mathrm{CH}_{2} \mathrm{Cl}_{2}(20 \mathrm{~mL}, 3$ times). The combined organic layer was washed by brine and dried over anhydrous $\mathrm{Na}_{2} \mathrm{SO}_{4}$. The crude mixture was concentrated and purified by flash column chromatography to provide $32(520 \mathrm{mg}, 91 \%)$ as colorless oil.

\section{Compound 33}

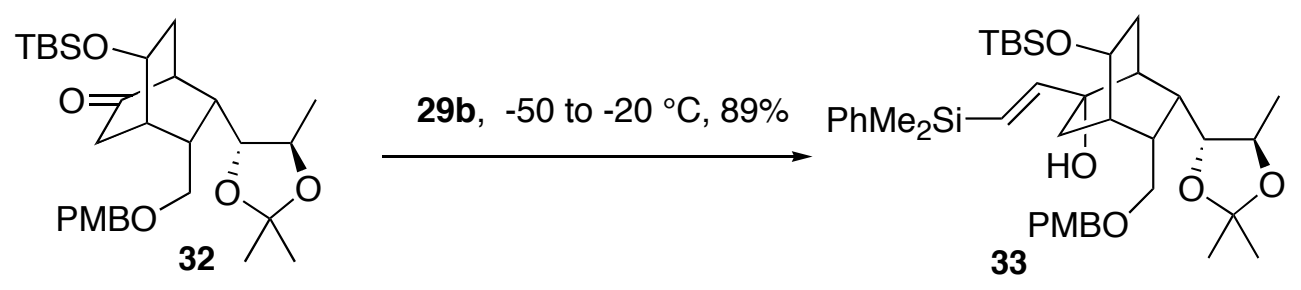

A $50 \mathrm{~mL}$ round bottom flask containing 29a $(1.81 \mathrm{~g}, 4.0 \mathrm{mmol})$ and $8 \mathrm{~mL}$ anhydrous THF was cooled to $-78{ }^{\circ} \mathrm{C}$. To this solution was added $n$-BuLi $(2.39 \mathrm{M}$ in hexanes, $1.67 \mathrm{~mL}, 4.0 \mathrm{mmol})$. The reaction was maintained at $-78{ }^{\circ} \mathrm{C}$ for 30 minutes and then warmed up to $-30{ }^{\circ} \mathrm{C}$ in 30 minutes. This reaction was cooled to $-78{ }^{\circ} \mathrm{C}$ and $32(650$ $\mathrm{mg}, 1.25 \mathrm{mmol}$ ) in $8 \mathrm{~mL}$ THF was added to this flask via a cannula. The flask was maintained at $-78{ }^{\circ} \mathrm{C}$ for 1.5 hours and then warmed up to $-20{ }^{\circ} \mathrm{C}$ in another 1.5 hours gradually. This reaction was quenched by $10 \mathrm{~mL}$ saturated aqueous sodium bicarbonate and diluted with $20 \mathrm{~mL}$ EtOAc. The organic layer was separated and the water layer was extracted by EtOAc $(10 \mathrm{~mL})$ for three times. The combined organic layer was washed by brine and dried over anhydrous $\mathrm{Na}_{2} \mathrm{SO}_{4}$. The crude mixture was concentrated under vacuum and purified by flash column chromatography to provide compound $\mathbf{3 3}$ (756 mg, $89 \%$ ) as colorless oil. 


\section{Compound 33a}

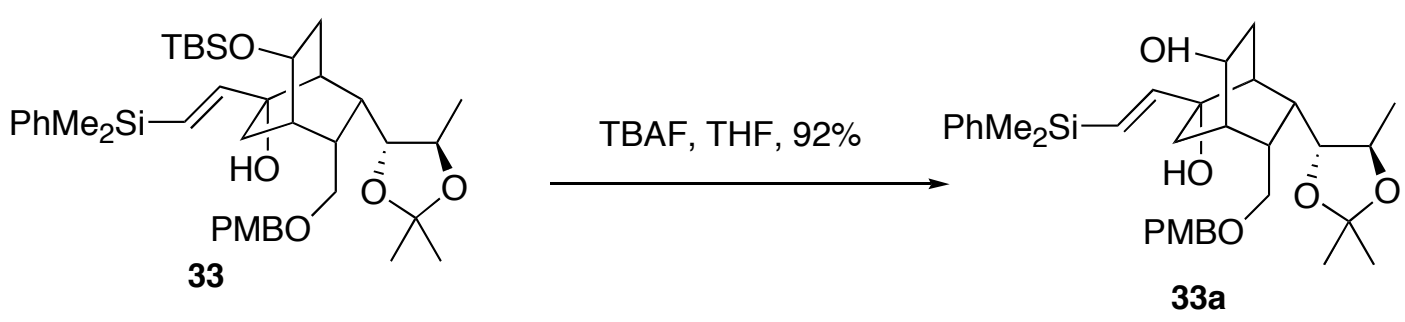

To a solution of 33 (592 mg, $0.869 \mathrm{mmol})$ in $15 \mathrm{~mL}$ THF was added TBAF (1.0 $\mathrm{M}$ in THF, $1.13 \mathrm{~mL}, 1.13 \mathrm{mmol}$ ). The reaction was heated at reflux for 3 hours and monitored by thin layer chromatography (Hexanes:EtOAc=5:1). The reaction mixture was then concentrated and purified by flash column chromatography to provide 33a (453 mg, $92 \%)$ as colorless oil.

\section{Compound 33b}
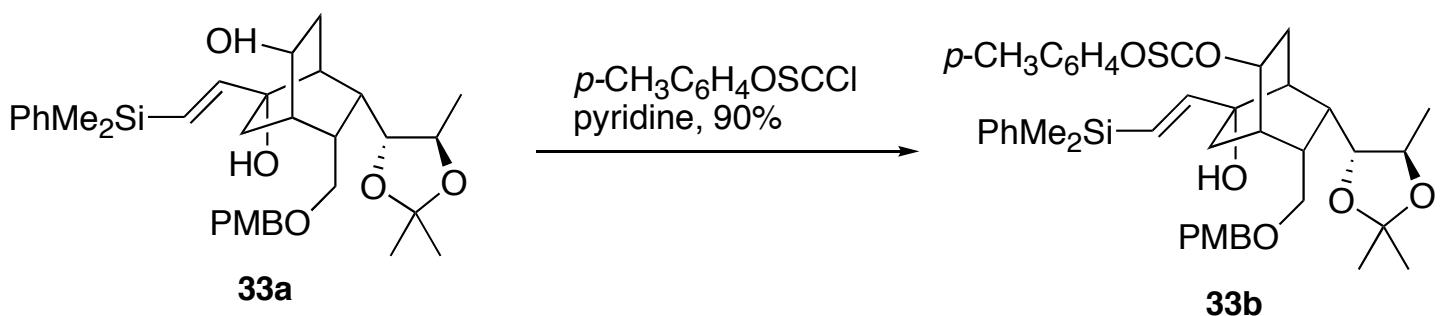

To a solution of 33a (508 mg, $0.896 \mathrm{mmol})$ in $15 \mathrm{~mL} \mathrm{CH}_{2} \mathrm{Cl}_{2}$ was added pyridine (213 mg, $2.69 \mathrm{mmol}$ ), and p-tolyl chlorothionoformate (385 mg, $2.06 \mathrm{mmol}$ ). This reaction was heated at reflux for 2 hours. Pyridine was removed under reduced pressure and $8 \mathrm{~mL}$ saturated aqueous $\mathrm{NaHCO}_{3}$ was added. The crude mixture was extracted with $\mathrm{CH}_{2} \mathrm{Cl}_{2}$ (15 mL, 3 times). The combined organic layer was washed with brine and dried over anhydrous $\mathrm{Na}_{2} \mathrm{SO}_{4}$. The crude mixture was concentrated under vacuum and purified by flash column chromatography to provide $\mathbf{3 3 b}$ (578 mg, 90\%) as colorless oil.

\section{Compound 30}

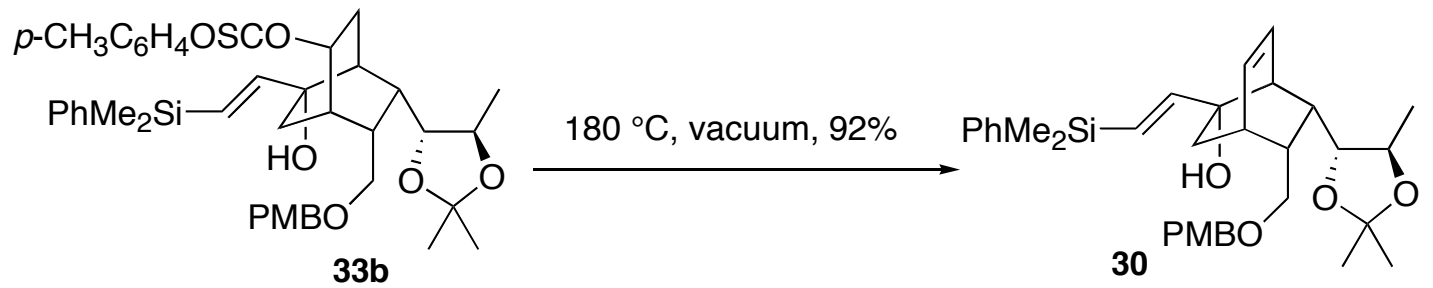


A $25 \mathrm{~mL}$ round bottom flask containing $33 \mathbf{b}(578 \mathrm{mg}, 0.806 \mathrm{mmol})$ was heated at $180{ }^{\circ} \mathrm{C}$ under vacuum for 2 hours. The crude mixture was purified by flash column chromatography to provide $\mathbf{3 0}$ (407mg, 92\%) as colorless oil.

\section{Compound 34}

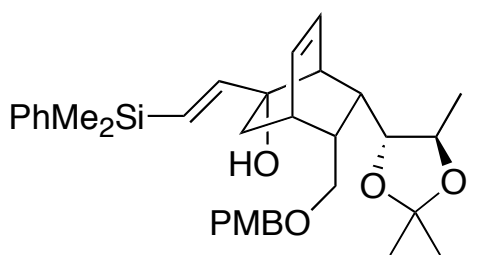

30
KHMDS, DME, 18-C-6

sealed tube, $115^{\circ} \mathrm{C}, 76 \%$

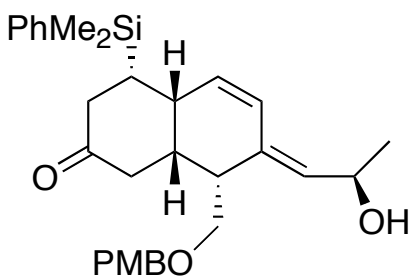

34

A solution of $30(34 \mathrm{mg}, 0.062 \mathrm{mmol})$ and $18-\mathrm{C}-6(32.8 \mathrm{mg}, 0.124 \mathrm{mmol})$ in anhydrous DME (1.5 mL) was added to a flame dried sealed tube via a cannula. KHMDS $(0.5 \mathrm{M}$ solution in toluene, $1.24 \mathrm{~mL}, 0.62 \mathrm{mmol})$ was added to the sealed tube via a cannula. After the sealed tube was heated at $115^{\circ} \mathrm{C}$ for 2 hours, this reaction was quenched with $2 \mathrm{~mL}$ saturated aqueous sodium bicarbonate and diluted with $\mathrm{Et}_{2} \mathrm{O}$. The organic layer was separated and the water layer was extracted by $\mathrm{Et}_{2} \mathrm{O}(5 \mathrm{~mL})$ for three times. The combined organic layer was dried over $\mathrm{Na}_{2} \mathrm{SO}_{4}$, concentrated under vacuum, and purified by flash column chromatography to provide compound 34 (23 $\mathrm{mg}, 76 \%$ ) as colorless oil.

\section{Compound 30a}

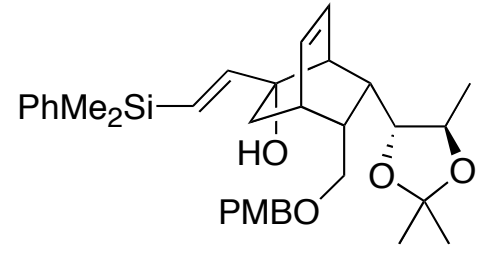

30

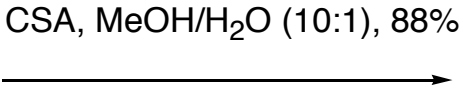

To a solution of $30(30.0 \mathrm{mg}, 0.0546 \mathrm{mmol})$ in $\mathrm{MeOH} / \mathrm{H}_{2} \mathrm{O}(1.5 \mathrm{~mL} / 0.15 \mathrm{~mL})$ was added CSA (1.3 mg, $0.0055 \mathrm{mmol})$. After stirring at room temperature for 24 hours, the reaction was completed. The reaction mixture was concentrated in vacuo and diluted with $5 \mathrm{~mL} \mathrm{Et}_{2} \mathrm{O}$. The organic layer was separated and the water layer was extracted by $\mathrm{Et}_{2} \mathrm{O}(5$ $\mathrm{mL}$ ) for three times. The combined organic layer was washed with brine and dried over 
anhydrous $\mathrm{Na}_{2} \mathrm{SO}_{4}$. The crude mixture was concentrated under vacuum and purified by flash column chromatography to provide compound $\mathbf{3 0 a}(24.5 \mathrm{mg}, 88 \%)$ as colorless oil.

\section{Compound 35}
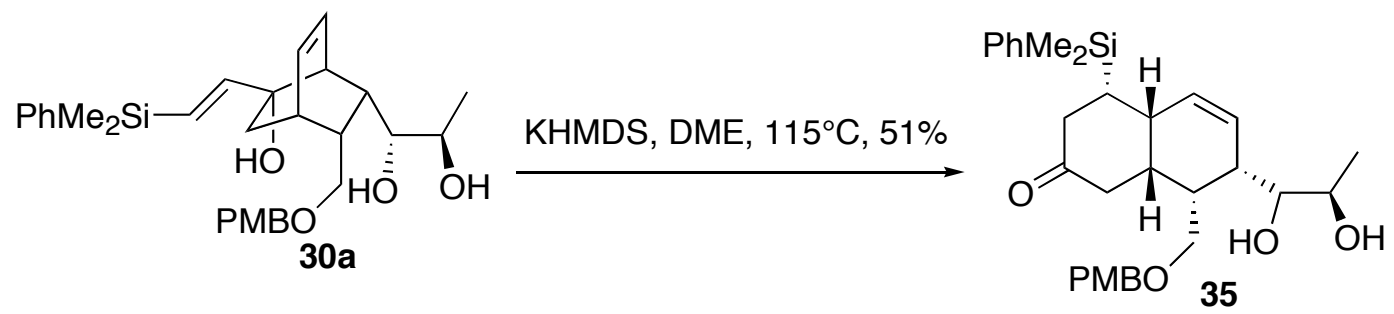

A solution of 30a (36 mg, $0.0707 \mathrm{mmol})$ in anhydrous DME $(2.0 \mathrm{~mL})$ was added to a flame dried sealed tube via a cannula. KHMDS $(0.5 \mathrm{M}$ solution in toluene, $1.13 \mathrm{~mL}$, $0.566 \mathrm{mmol}$ ) was also added to the sealed tube via a cannula. After the sealed tube was heated at $115{ }^{\circ} \mathrm{C}$ for 2 hours, this reaction was quenched with $2 \mathrm{~mL}$ saturated aqueous sodium bicarbonate and diluted with $8 \mathrm{~mL} \mathrm{Et}_{2} \mathrm{O}$. The organic layer was separated and the water layer was extracted by $\mathrm{Et}_{2} \mathrm{O}(8 \mathrm{~mL})$ for three times. The combined organic layer was washed with brine and dried over anhydrous $\mathrm{Na}_{2} \mathrm{SO}_{4}$. The crude mixture was concentrated in vacuo and purified by flash column chromatography to provide desired product 35 as a white solid (18 $\mathrm{mg}, 51 \%$ based on recovered starting material) and recover $1 \mathrm{mg}$ starting material. 


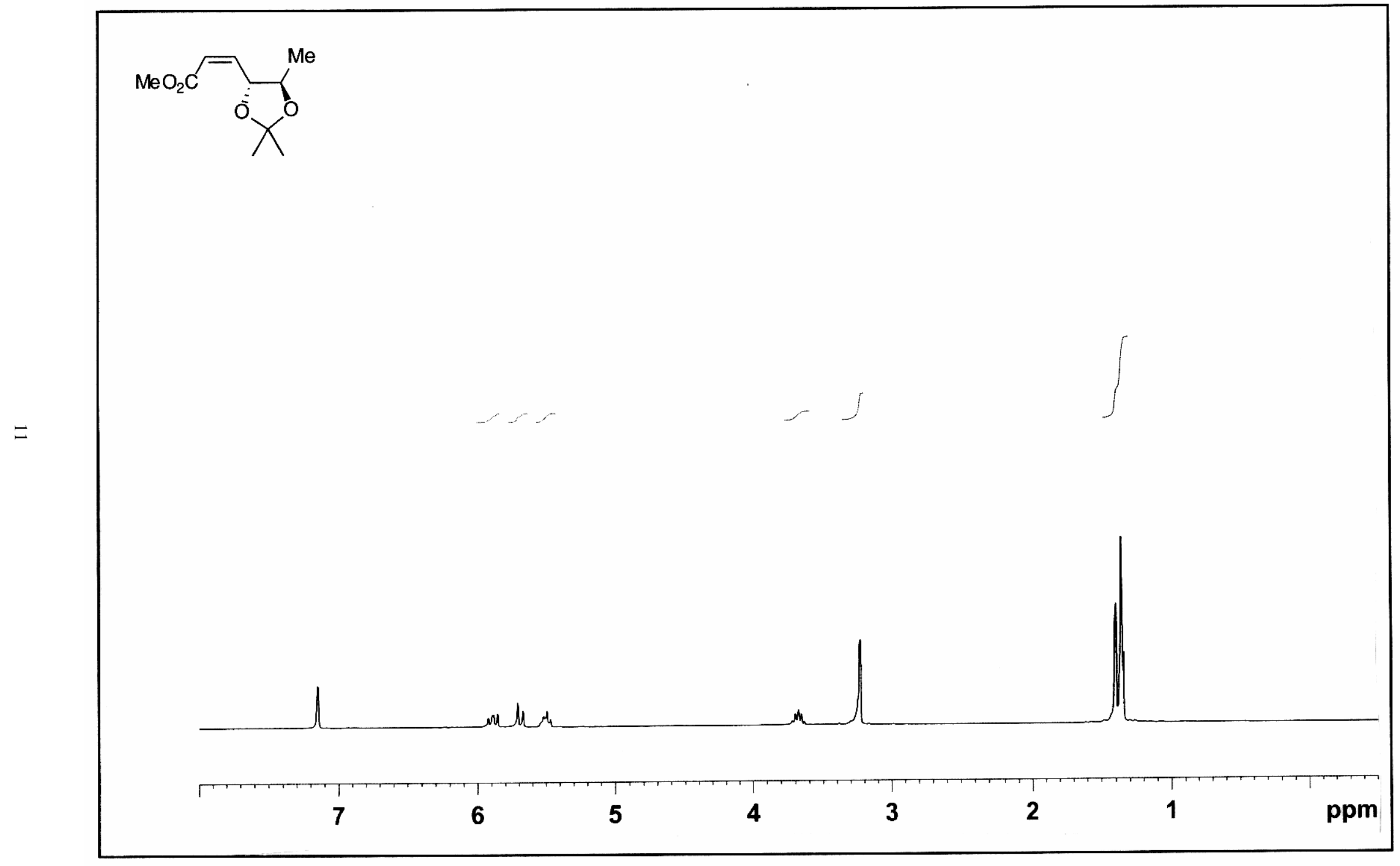

$300 \mathrm{MHz}{ }^{1} \mathrm{H}$ NMR of Compound $23\left(\mathrm{C}_{6} \mathrm{D}_{6}\right)$ 


$$
\text { L }
$$




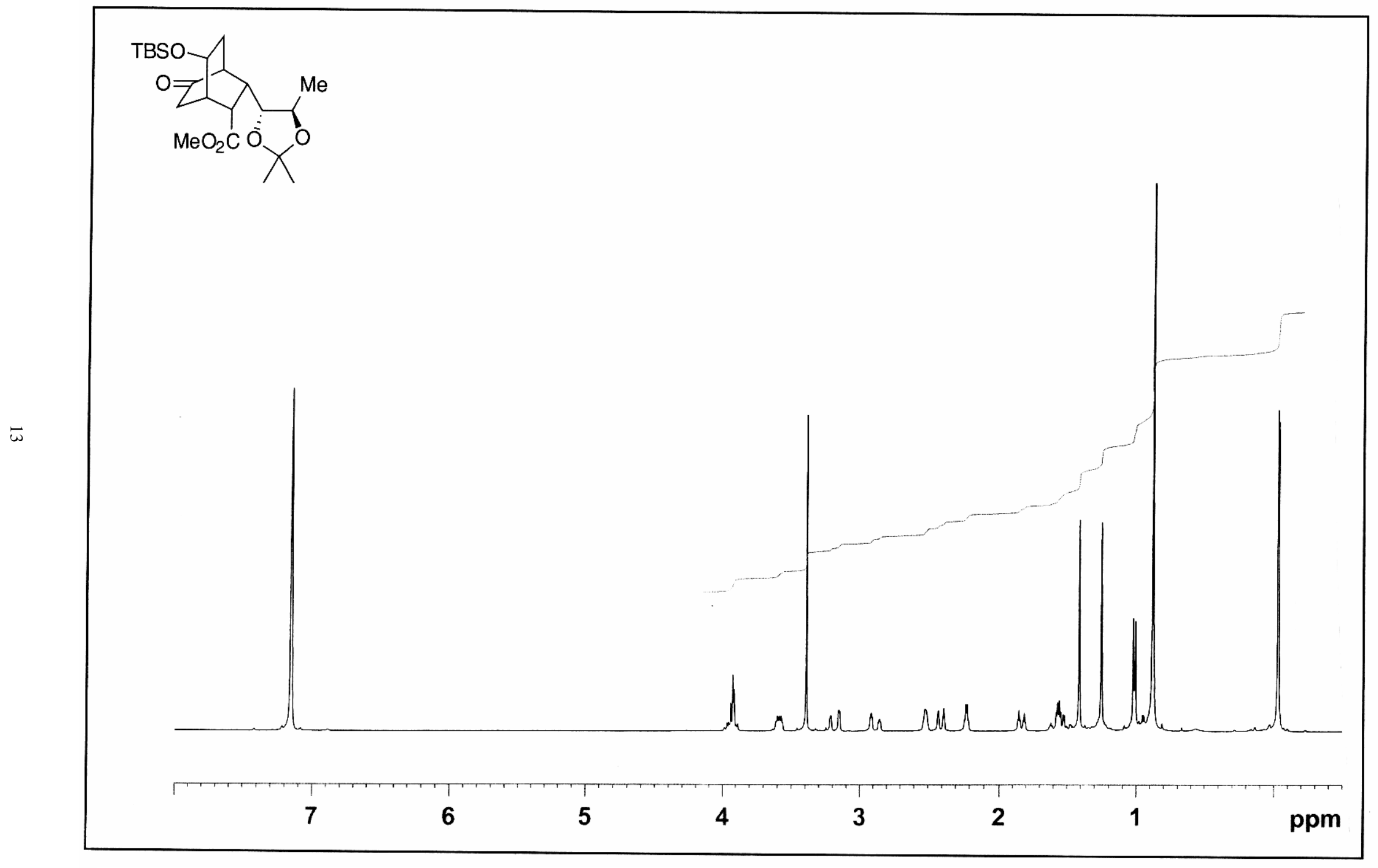

$300 \mathrm{MHz}{ }^{1} \mathrm{H}$ NMR of Compound $24\left(\mathrm{C}_{6} \mathrm{D}_{6}\right)$ 


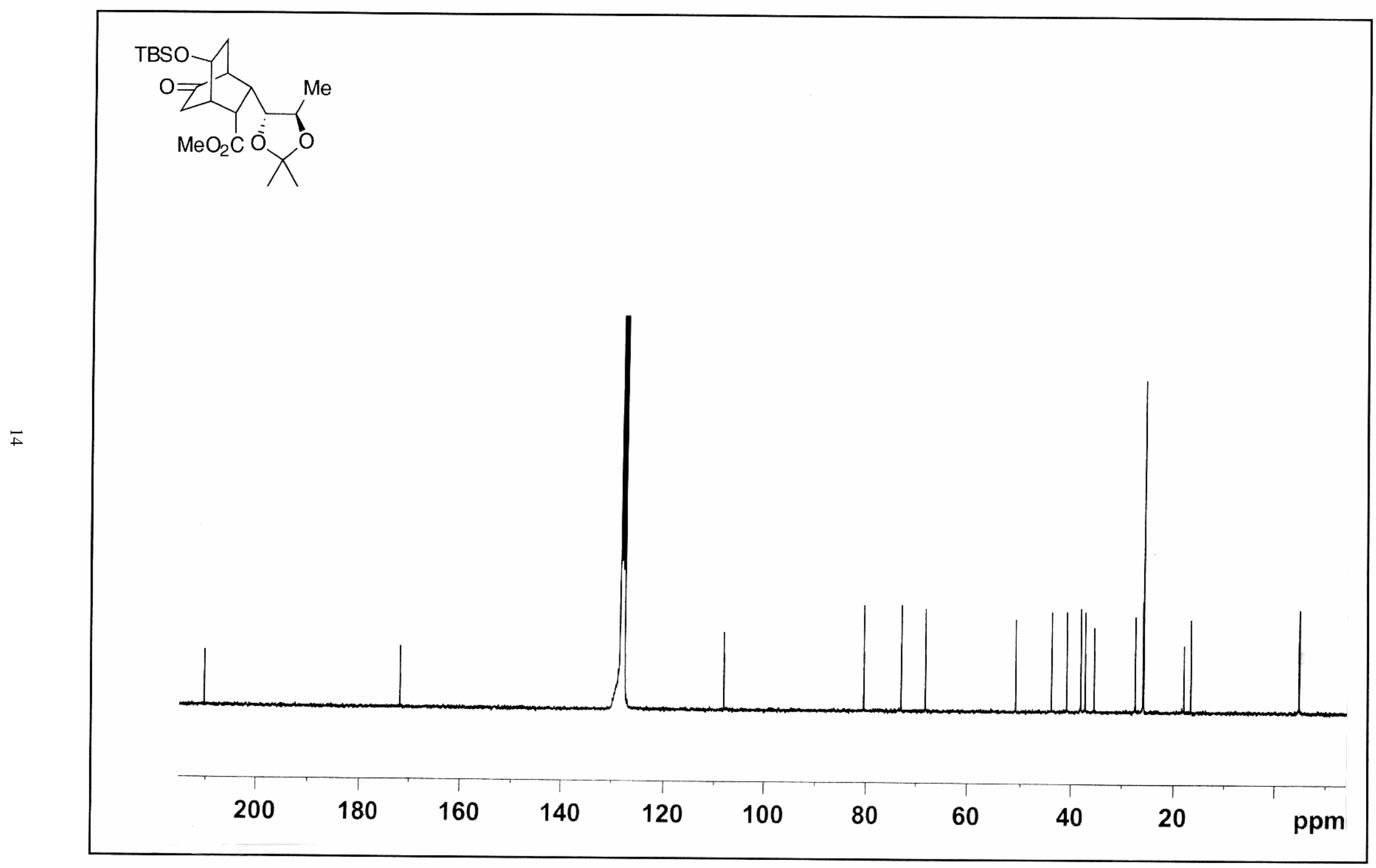

$75 \mathrm{MHz}{ }^{13} \mathrm{C}$ NMR of Compound $24\left(\mathrm{C}_{6} \mathrm{D}_{6}\right)$ 


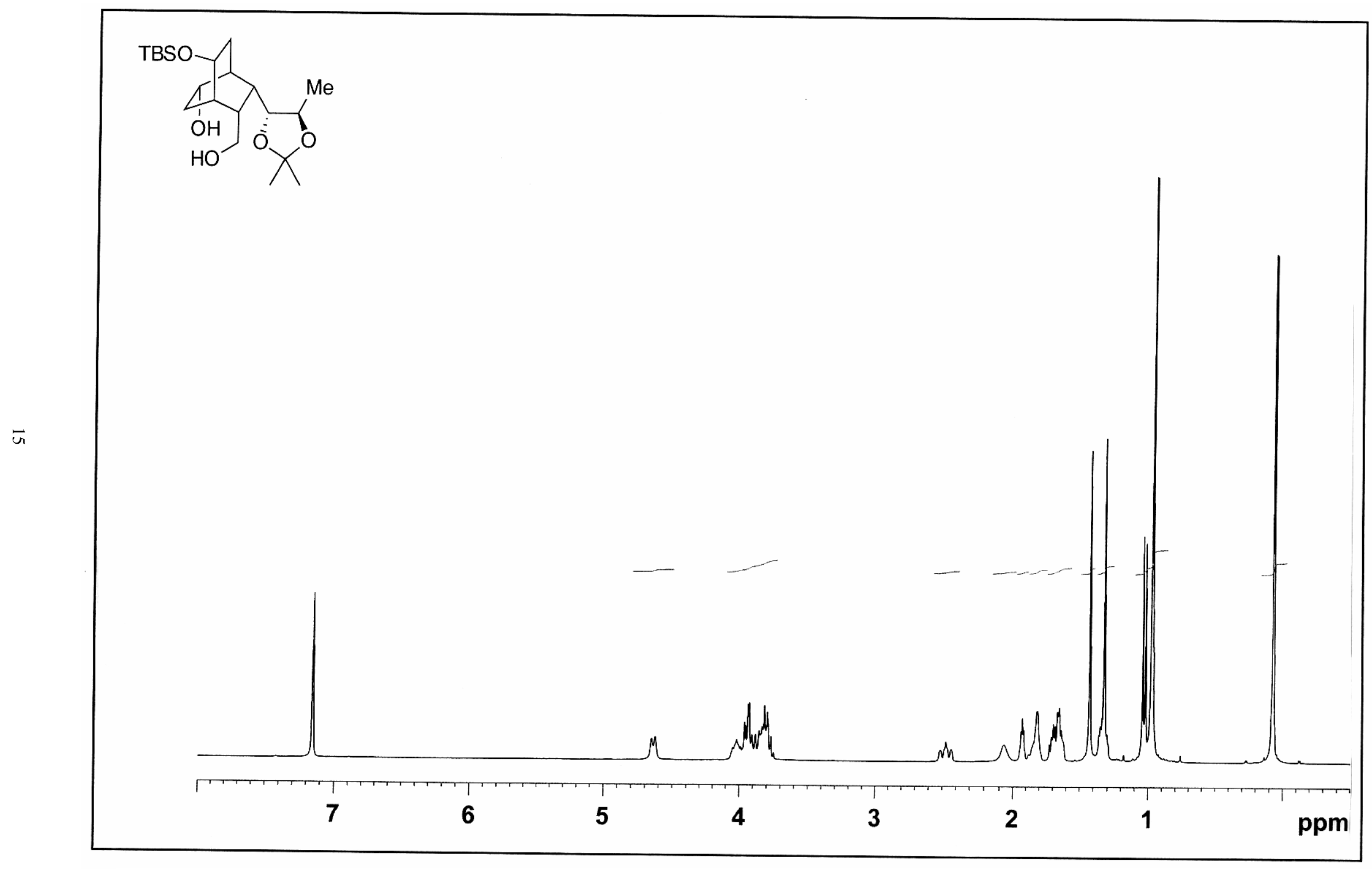

$300 \mathrm{MHz}{ }^{1} \mathrm{H}$ NMR of Compound $25\left(\mathrm{C}_{6} \mathrm{D}_{6}\right)$ 


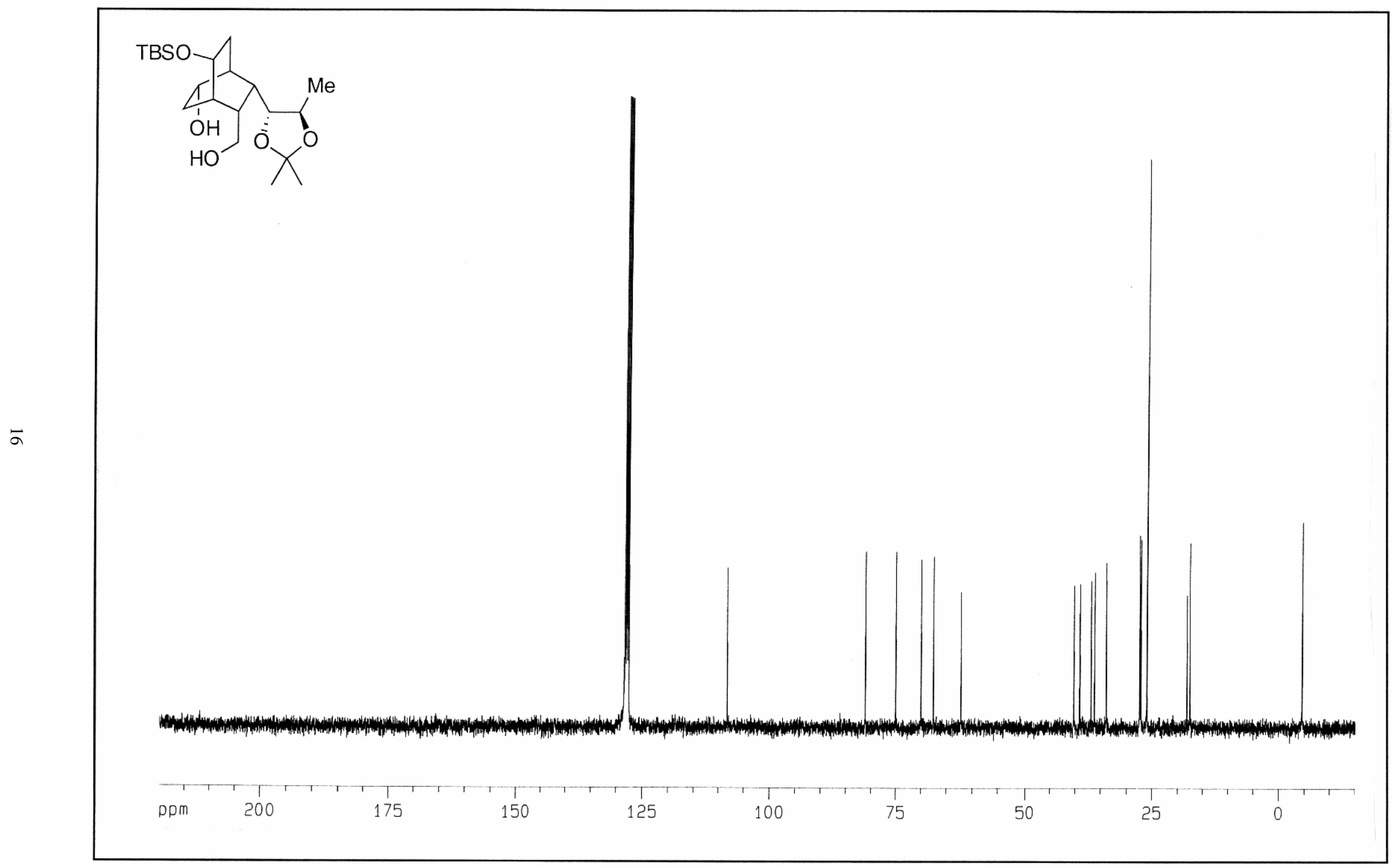

$75 \mathrm{MHz}{ }^{13} \mathrm{C}$ NMR of Compound $25\left(\mathrm{C}_{6} \mathrm{D}_{6}\right)$ 


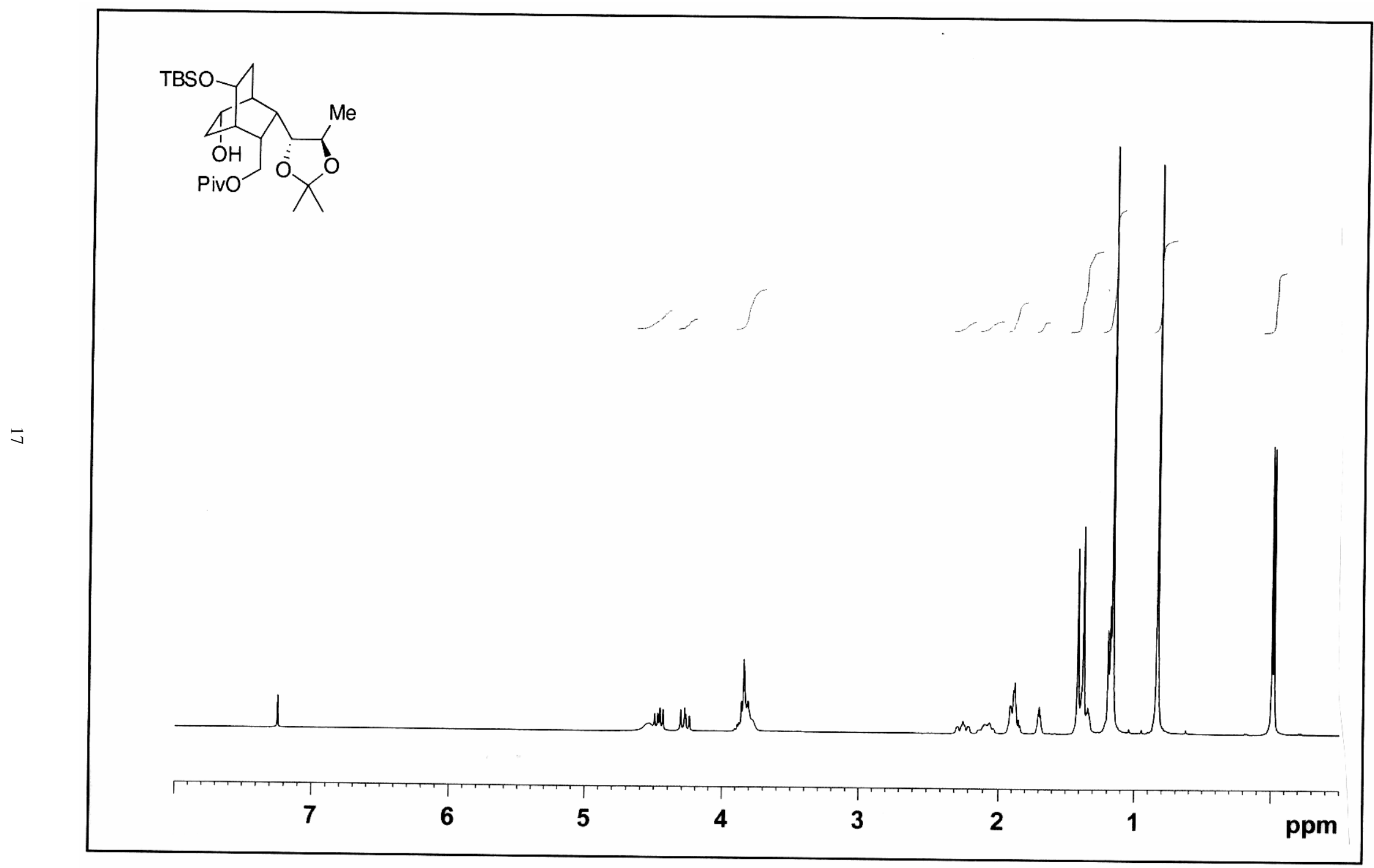

$300 \mathrm{MHz}{ }^{1} \mathrm{H}$ NMR of Compound 25a $\left(\mathrm{CDCl}_{3}\right)$ 


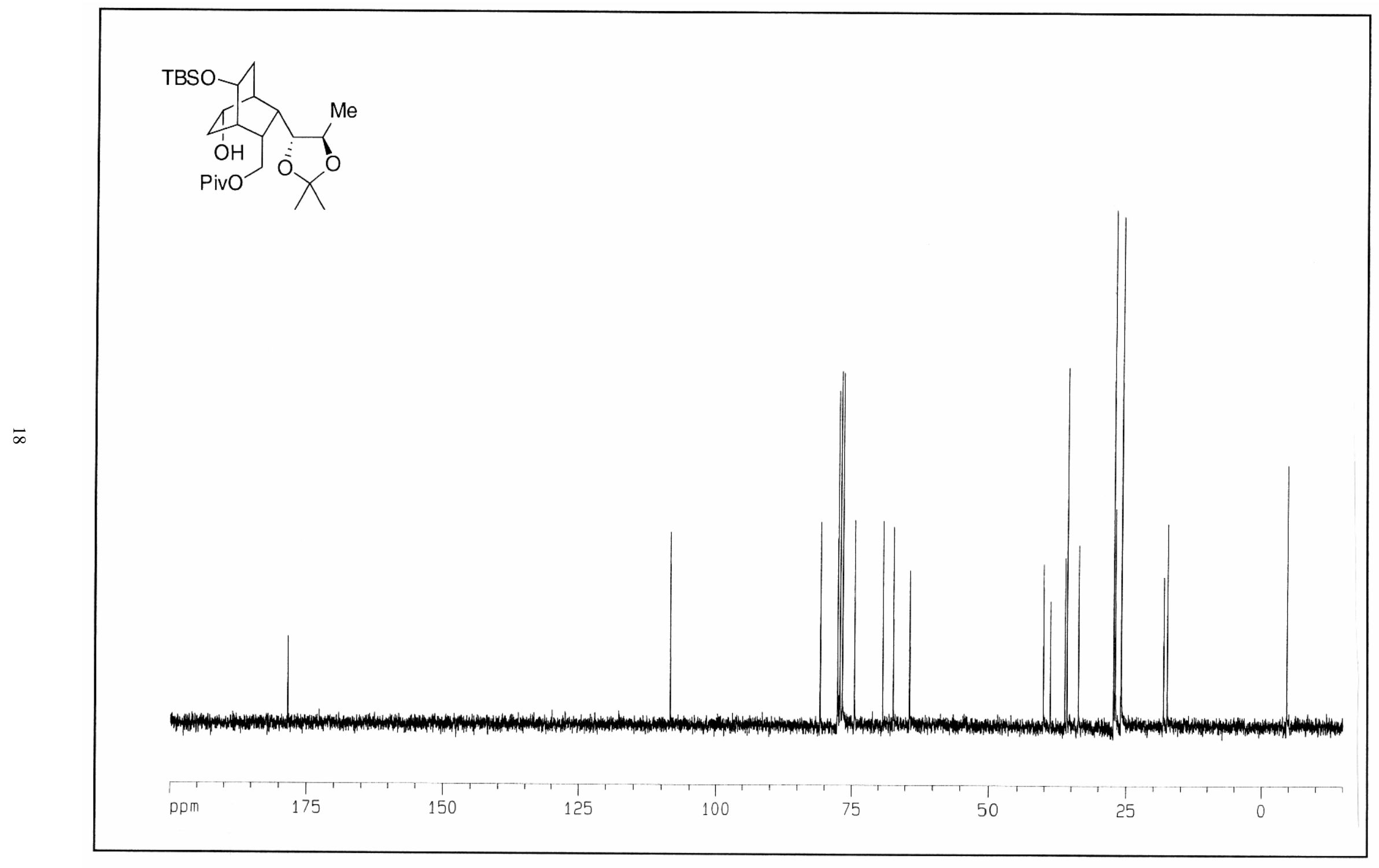

$75 \mathrm{MHz}{ }^{13} \mathrm{C}$ NMR of Compound 25a $\left(\mathrm{CDCl}_{3}\right)$ 


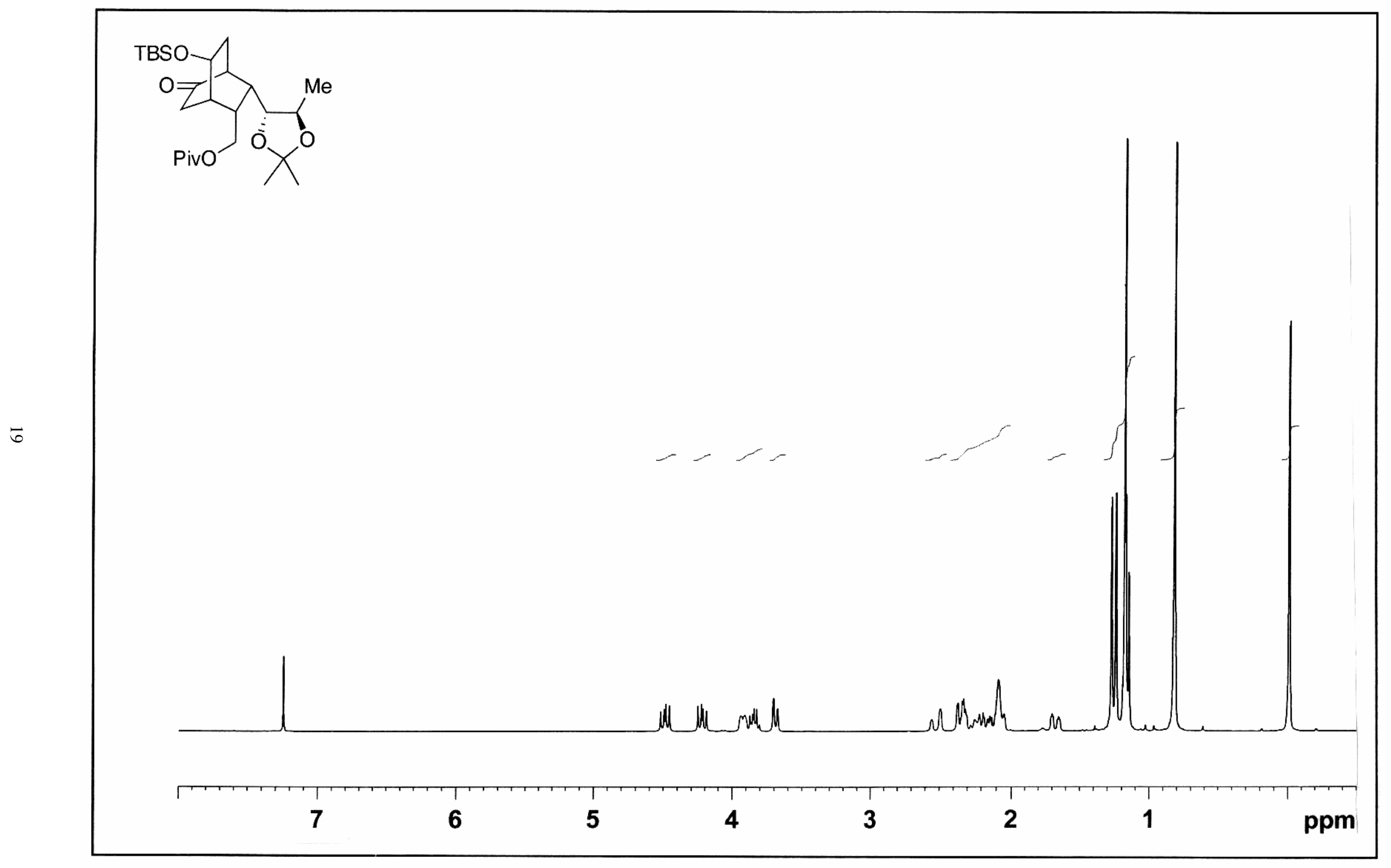

$300 \mathrm{MHz}{ }^{1} \mathrm{H}$ NMR of Compound $26\left(\mathrm{CDCl}_{3}\right)$ 


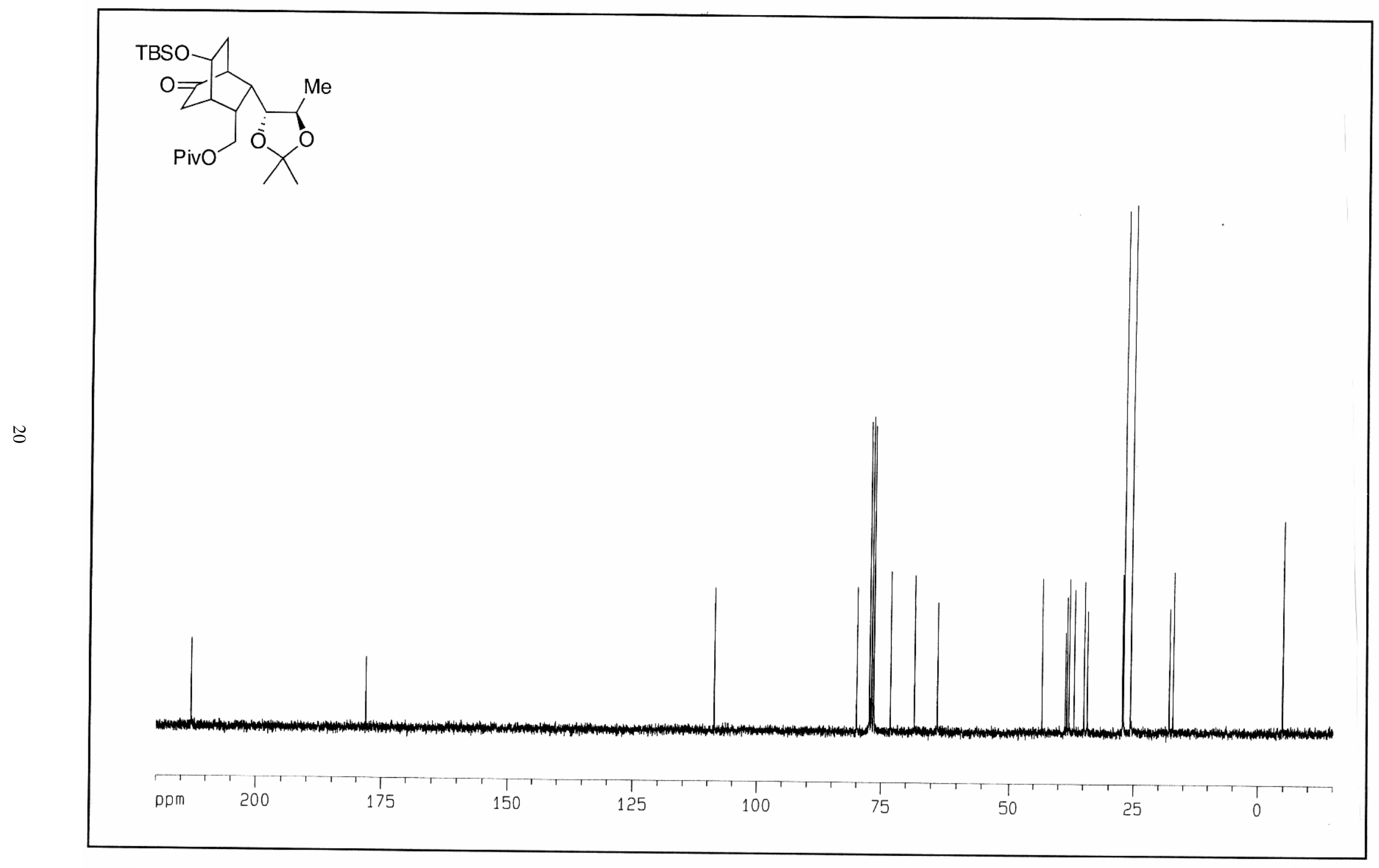

$75 \mathrm{MHz}{ }^{13} \mathrm{C}$ NMR of Compound $26\left(\mathrm{CDCl}_{3}\right)$ 


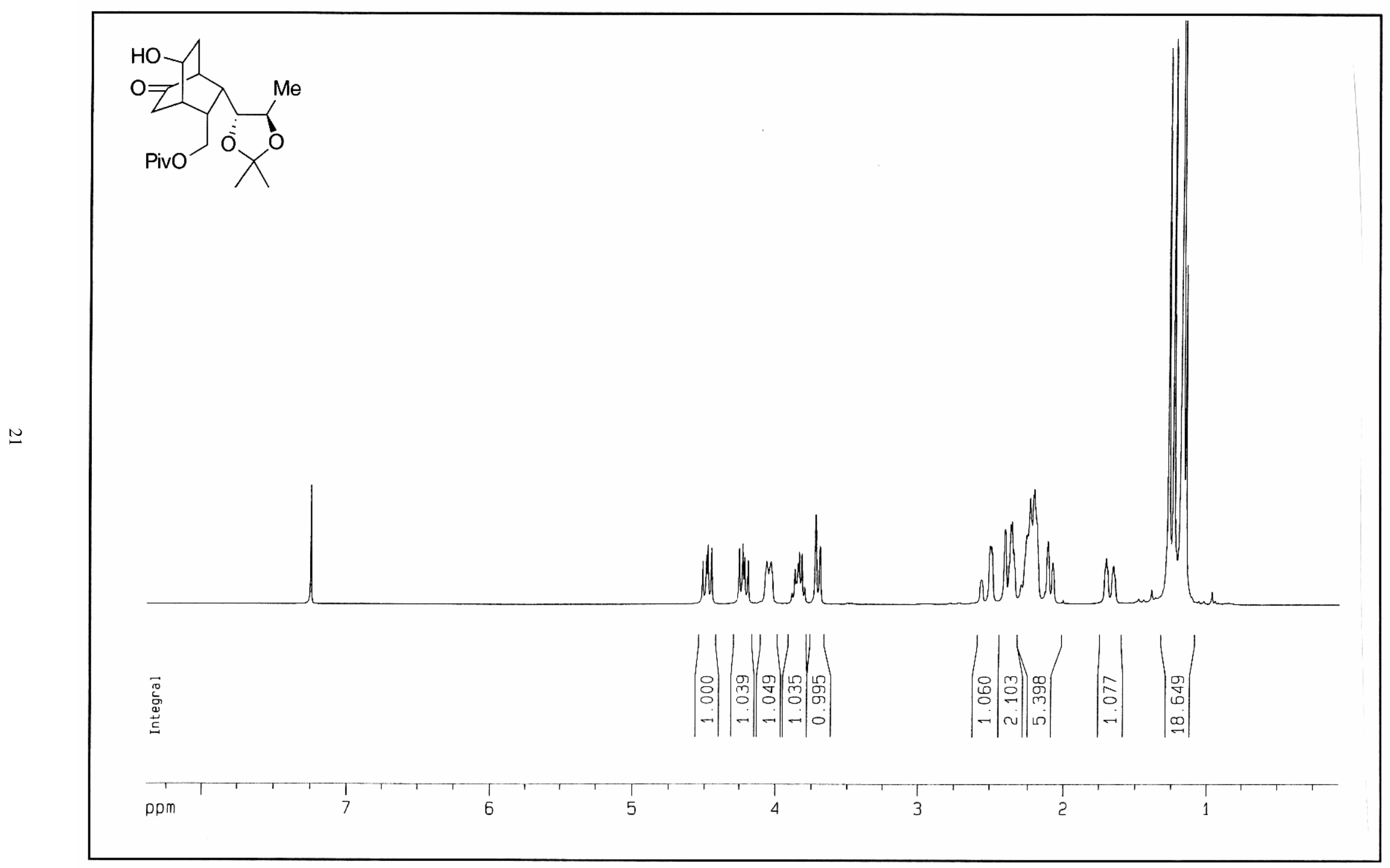

$300 \mathrm{MHz}{ }^{1} \mathrm{H}$ NMR of Compound 26a $\left(\mathrm{CDCl}_{3}\right)$ 


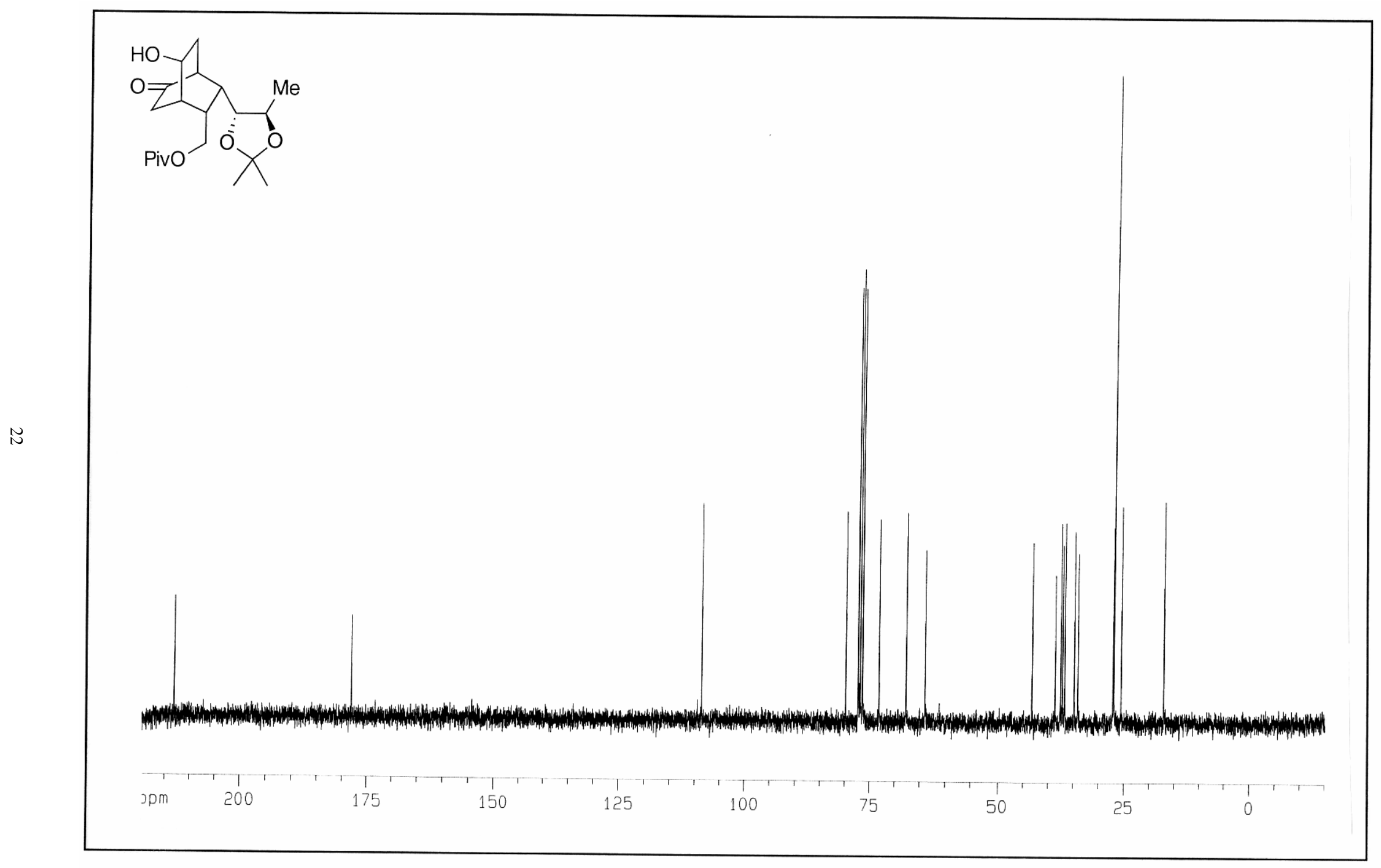

$75 \mathrm{MHz}{ }^{13} \mathrm{C}$ NMR of Compound 26a $\left(\mathrm{CDCl}_{3}\right)$ 


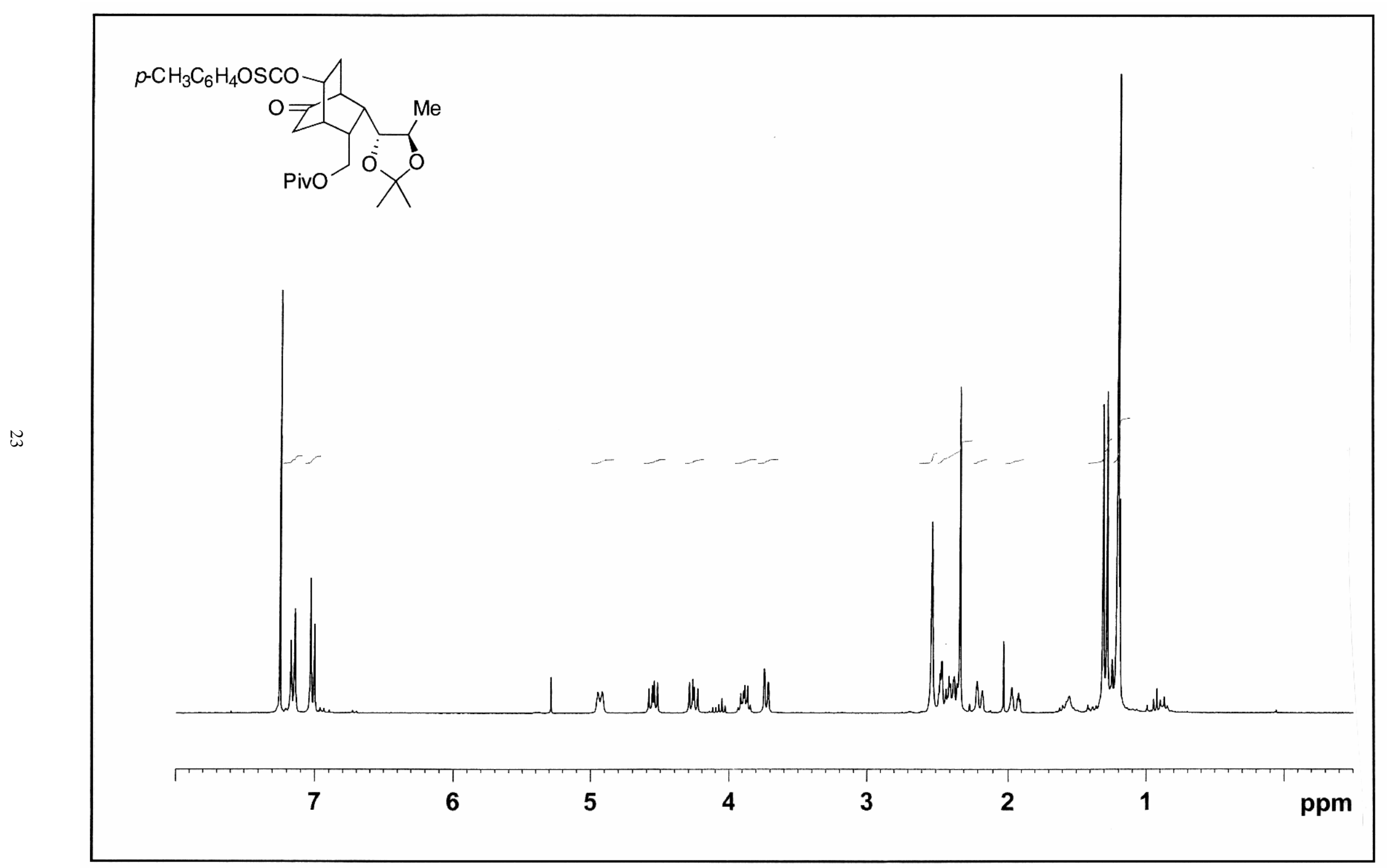

$300 \mathrm{MHz}{ }^{1} \mathrm{H}$ NMR of Compound 26b $\left(\mathrm{CDCl}_{3}\right)$ 


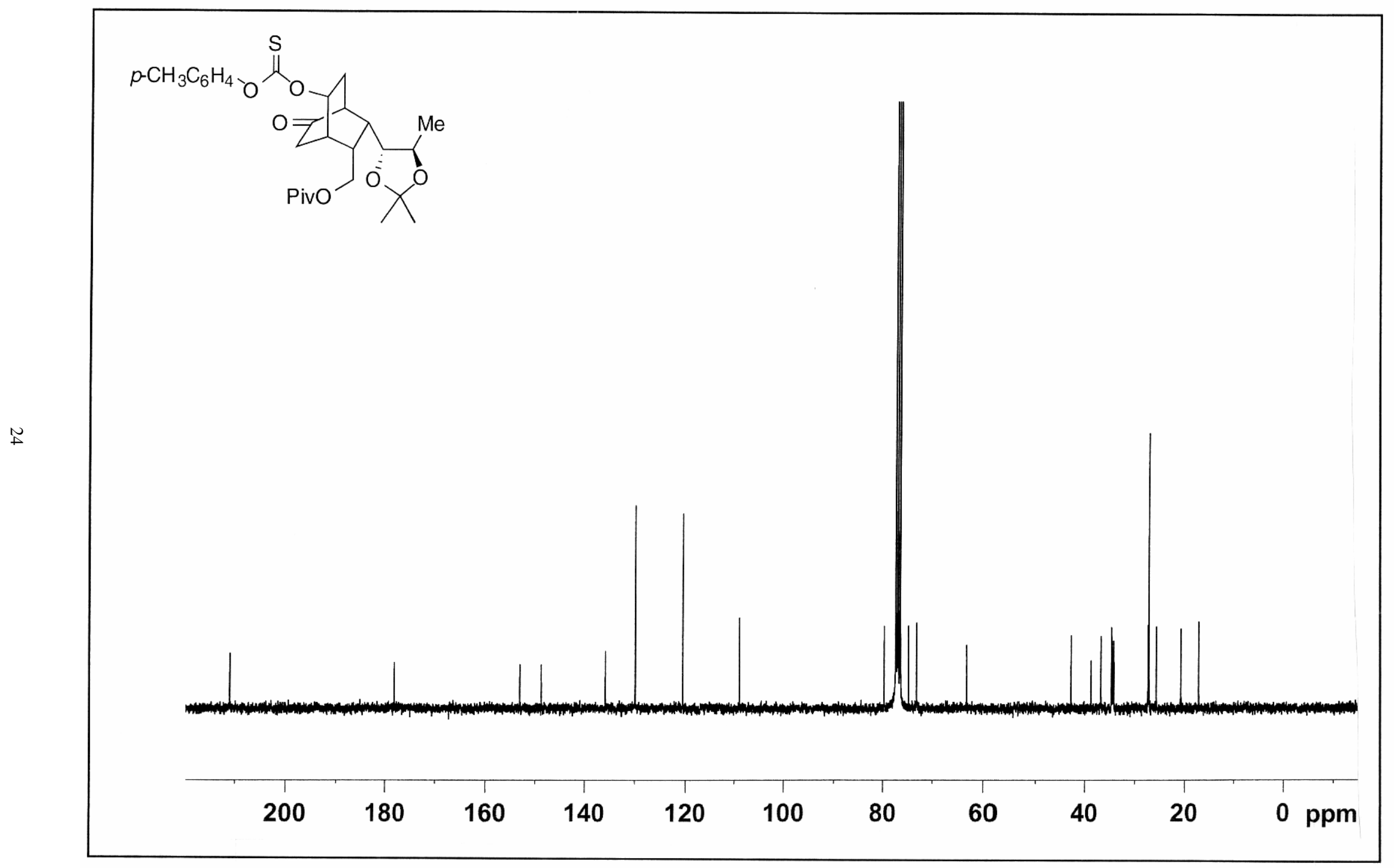

$75 \mathrm{MHz}{ }^{13} \mathrm{C}$ NMR of Compound $26 \mathbf{b}\left(\mathrm{CDCl}_{3}\right)$ 


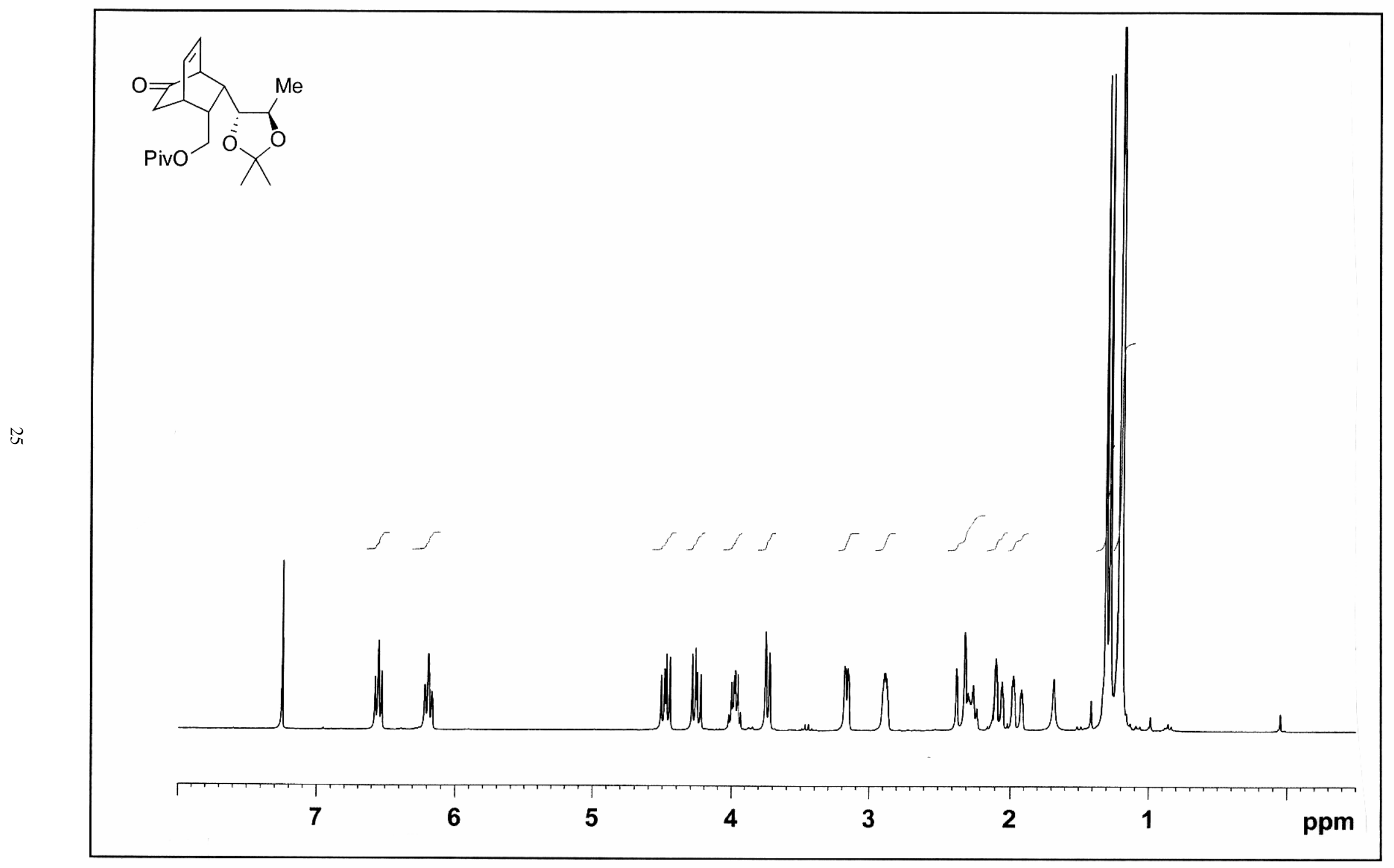

$300 \mathrm{MHz}{ }^{1} \mathrm{H}$ NMR of Compound $27\left(\mathrm{CDCl}_{3}\right)$ 


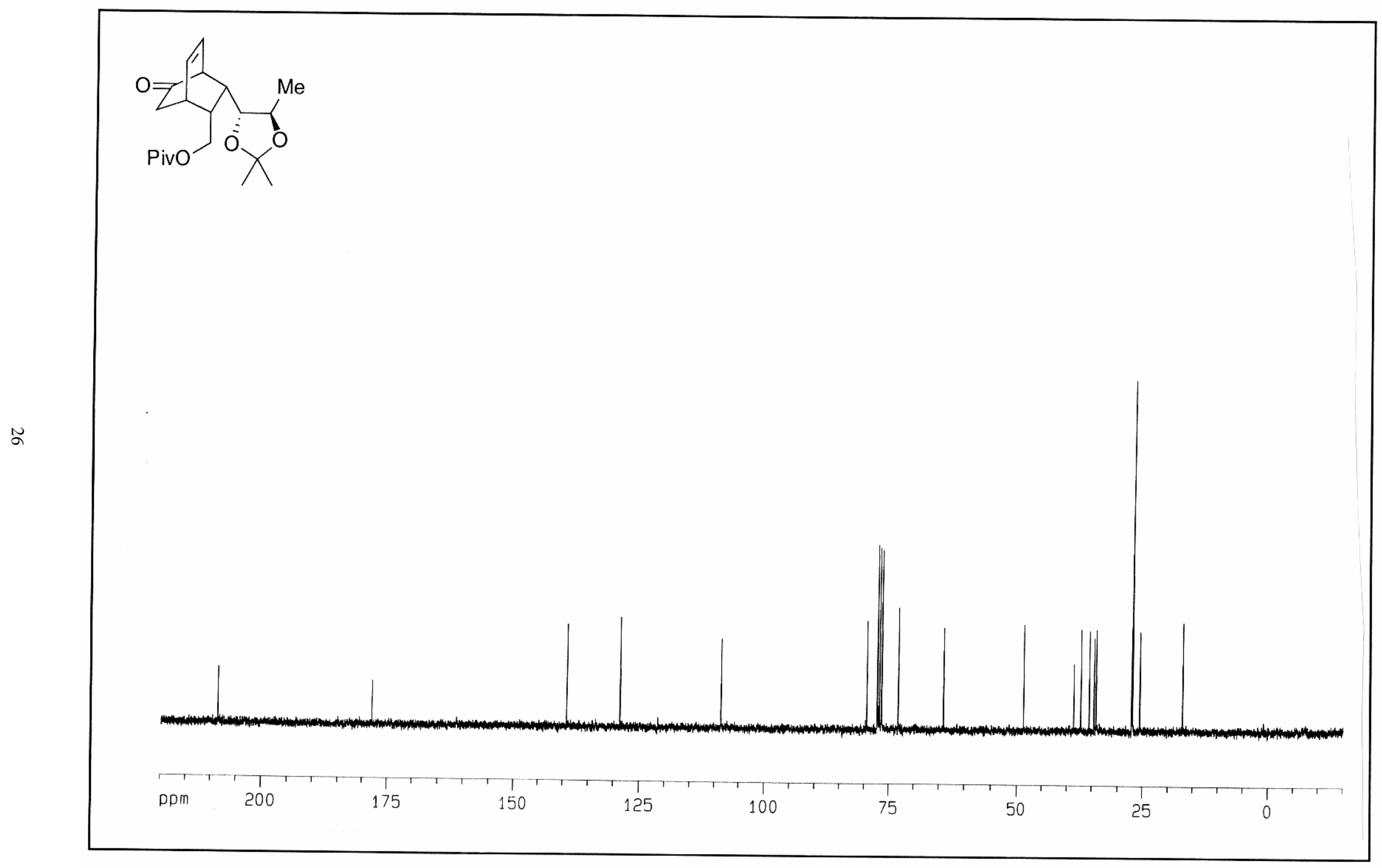

$75 \mathrm{MHz}{ }^{13} \mathrm{C}$ NMR of Compound $27\left(\mathrm{CDCl}_{3}\right)$ 


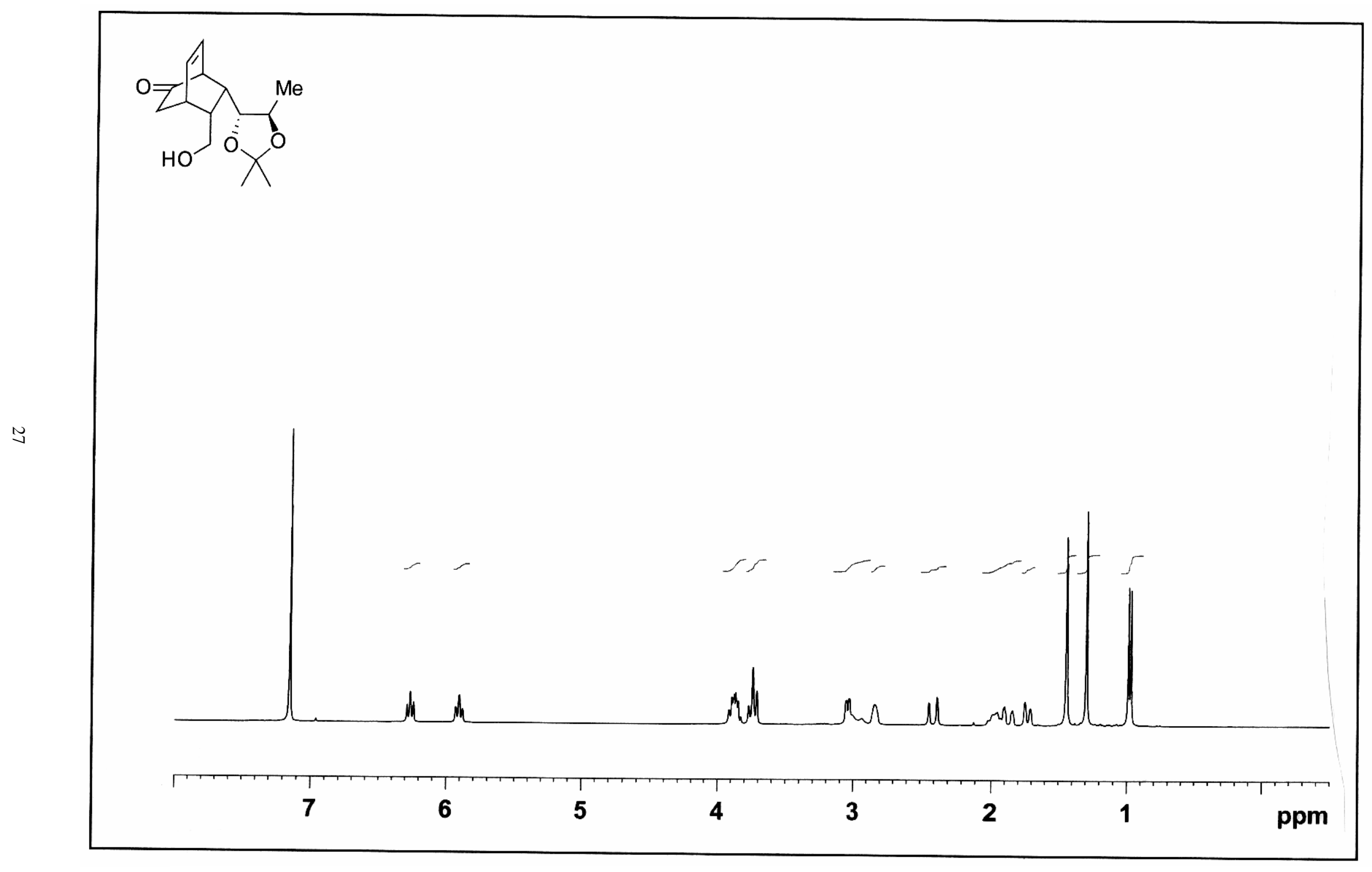

$300 \mathrm{MHz}{ }^{1} \mathrm{H}$ NMR of Compound 27a $\left(\mathrm{C}_{6} \mathrm{D}_{6}\right)$ 


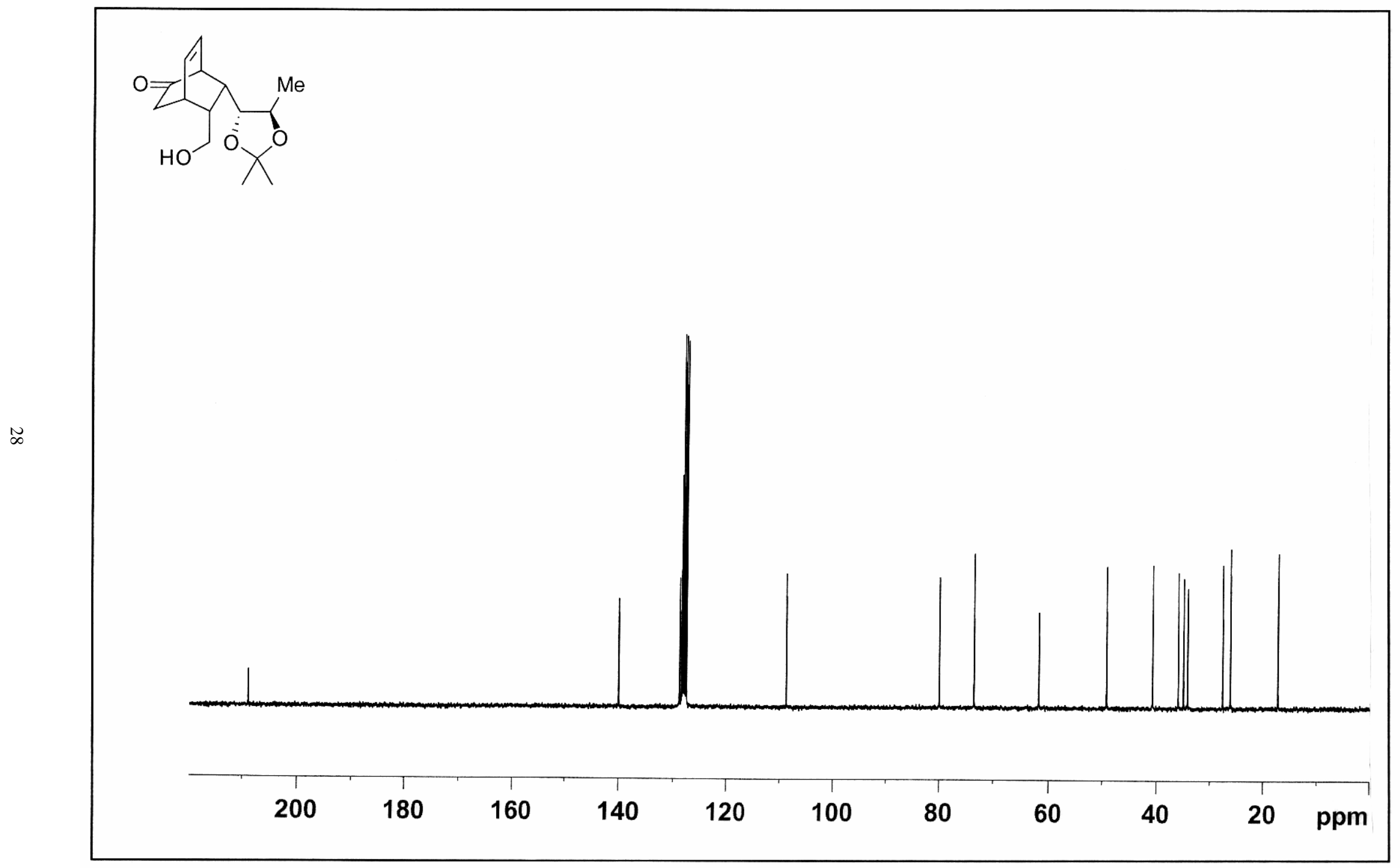

$75 \mathrm{MHz}{ }^{13} \mathrm{C}$ NMR of Compound 27a $\left(\mathrm{C}_{6} \mathrm{D}_{6}\right)$ 


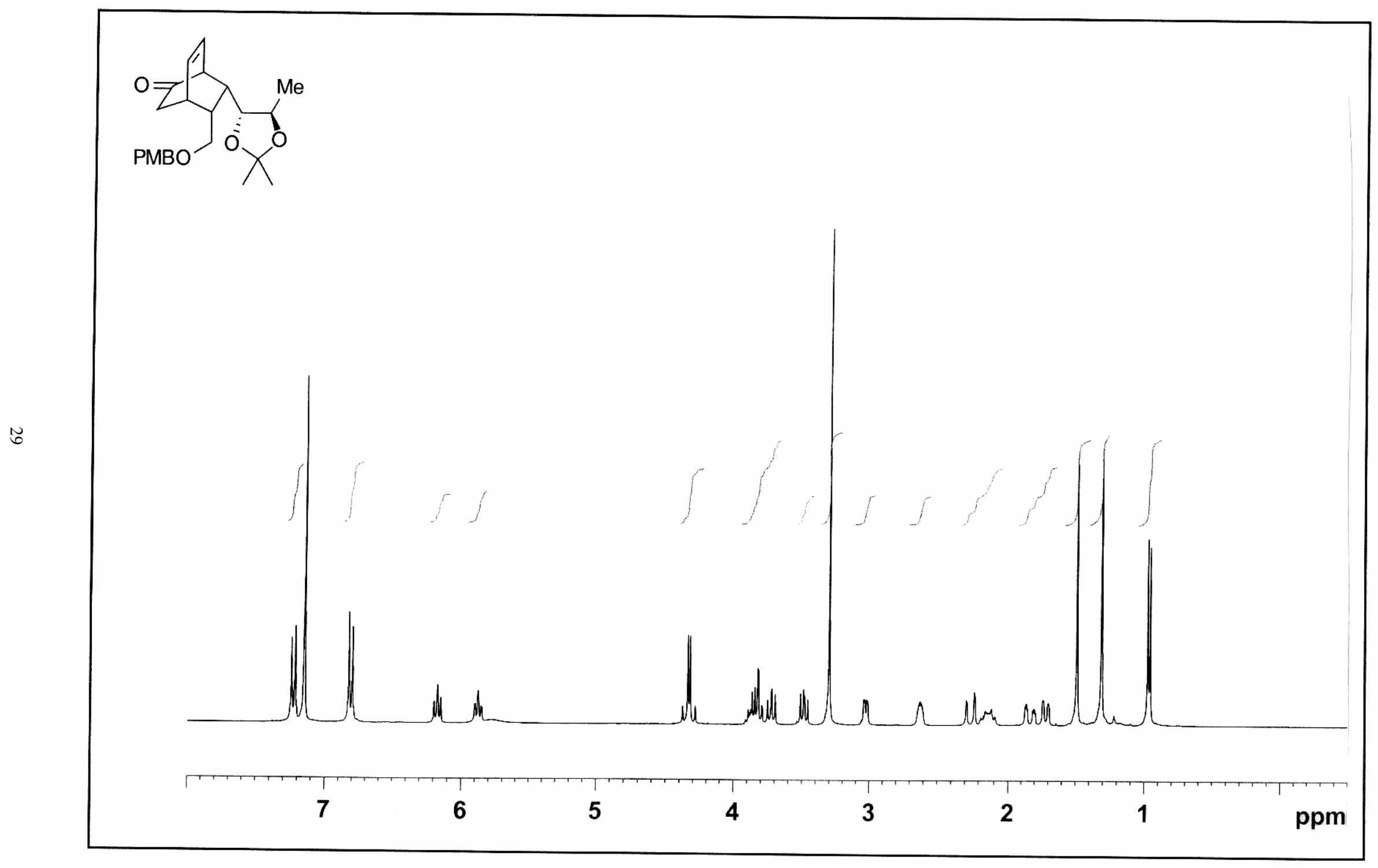

$300 \mathrm{MHz}{ }^{1} \mathrm{H}$ NMR of Compound $28\left(\mathrm{C}_{6} \mathrm{D}_{6}\right)$ 


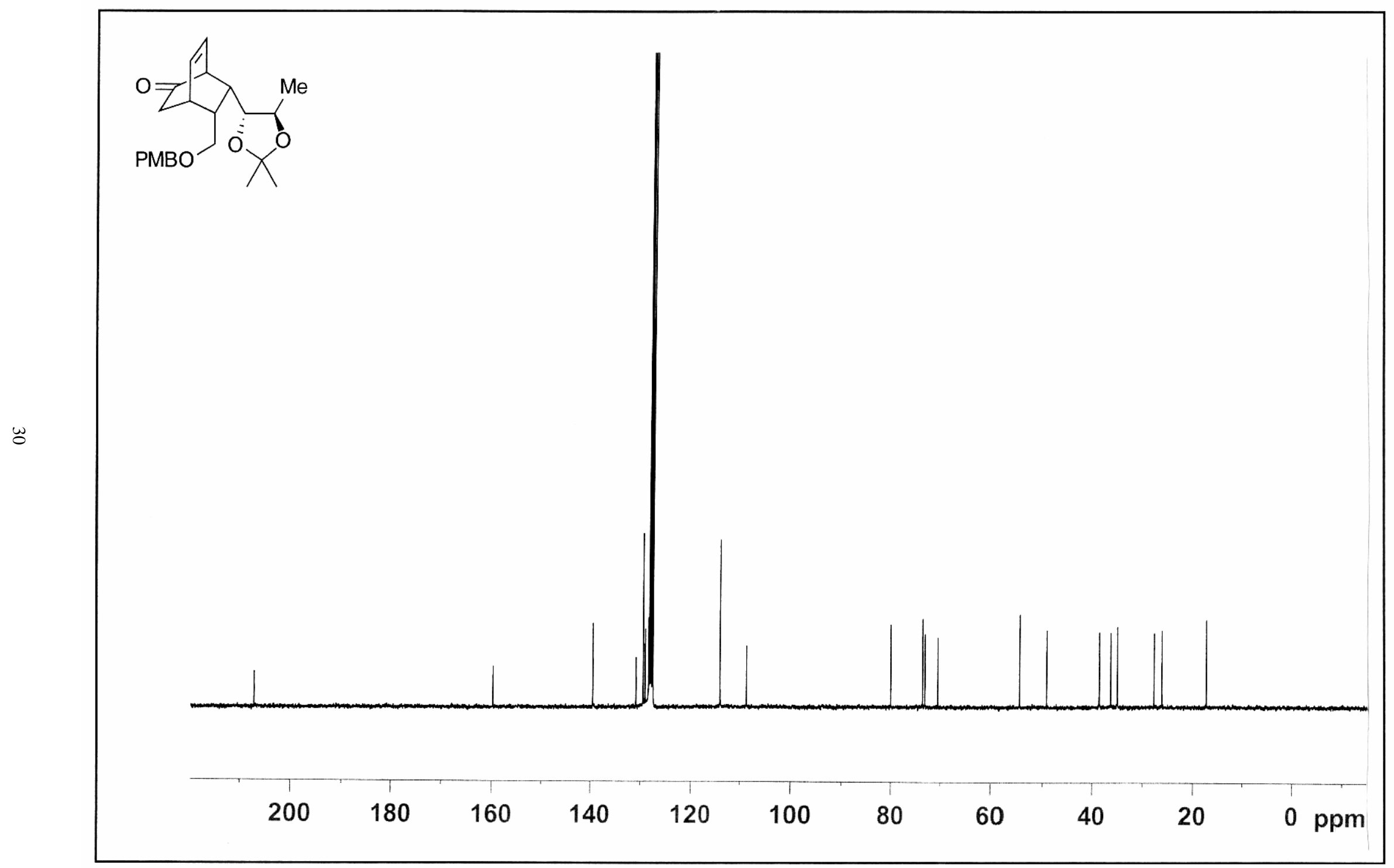

$75 \mathrm{MHz}{ }^{13} \mathrm{C}$ NMR of Compound $28\left(\mathrm{C}_{6} \mathrm{D}_{6}\right)$ 


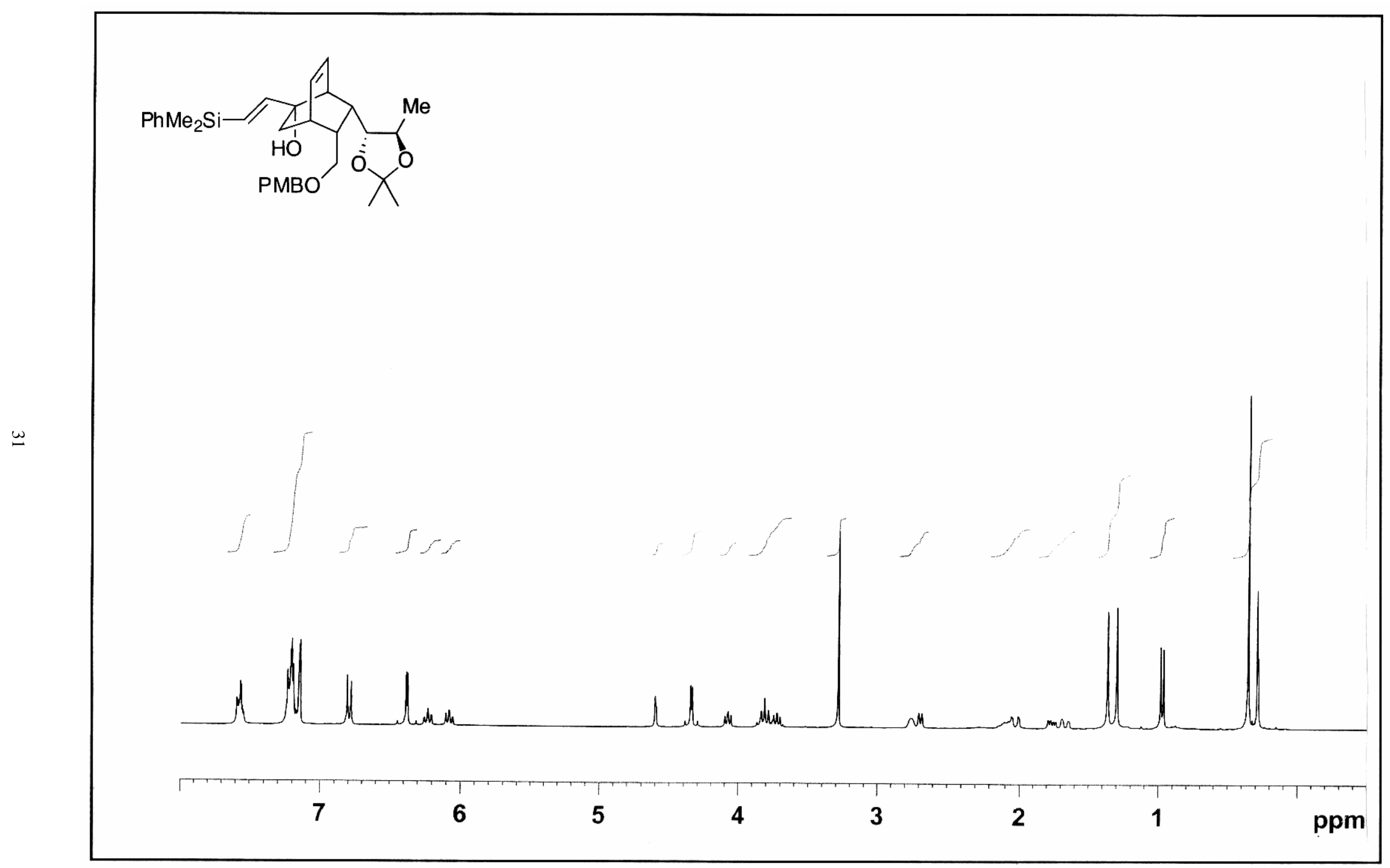

$300 \mathrm{MHz}{ }^{1} \mathrm{H}$ NMR of Compound $30\left(\mathrm{C}_{6} \mathrm{D}_{6}\right)$ 


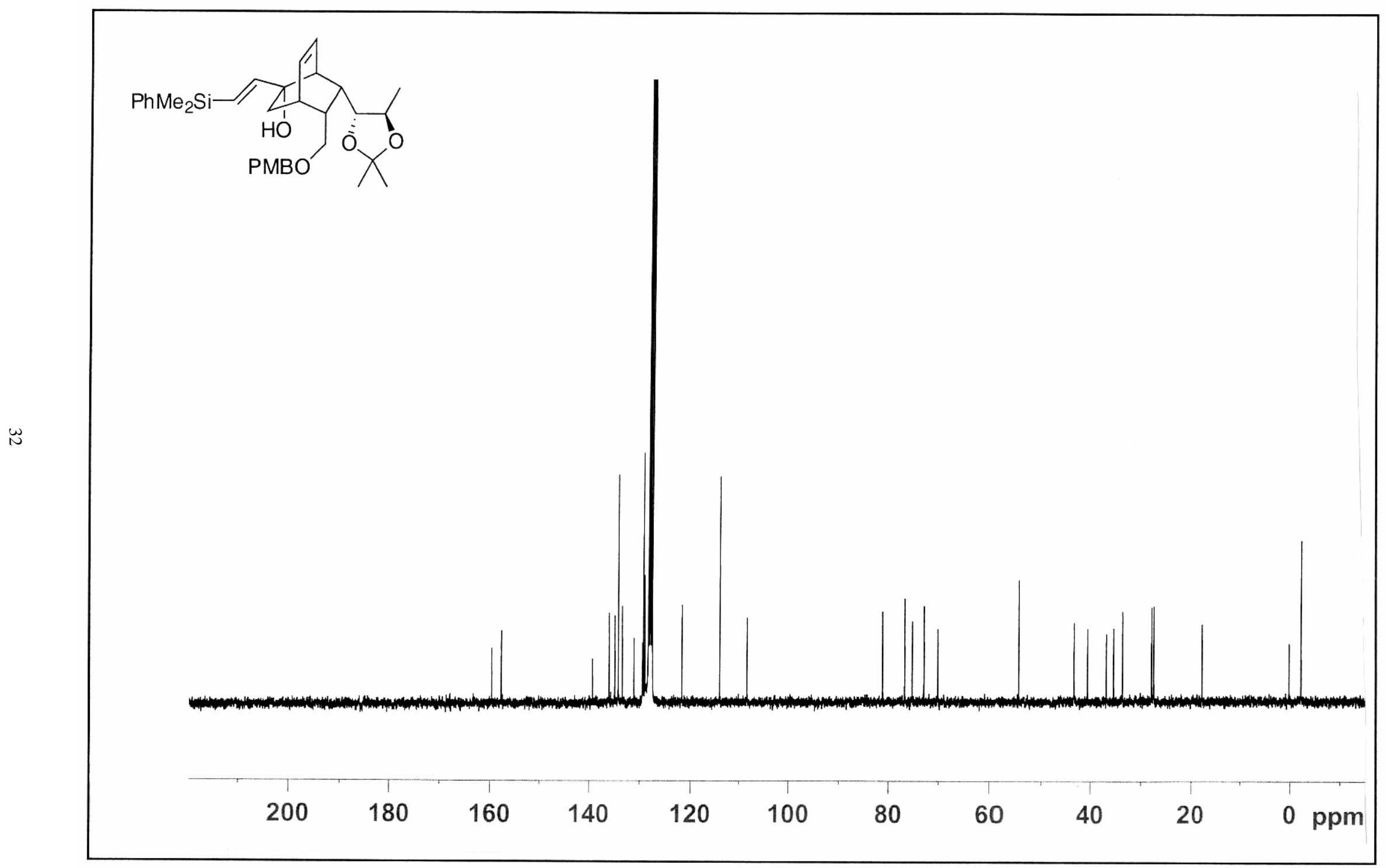

$75 \mathrm{MHz}{ }^{13} \mathrm{C}$ NMR of Compound $30\left(\mathrm{C}_{6} \mathrm{D}_{6}\right)$ 


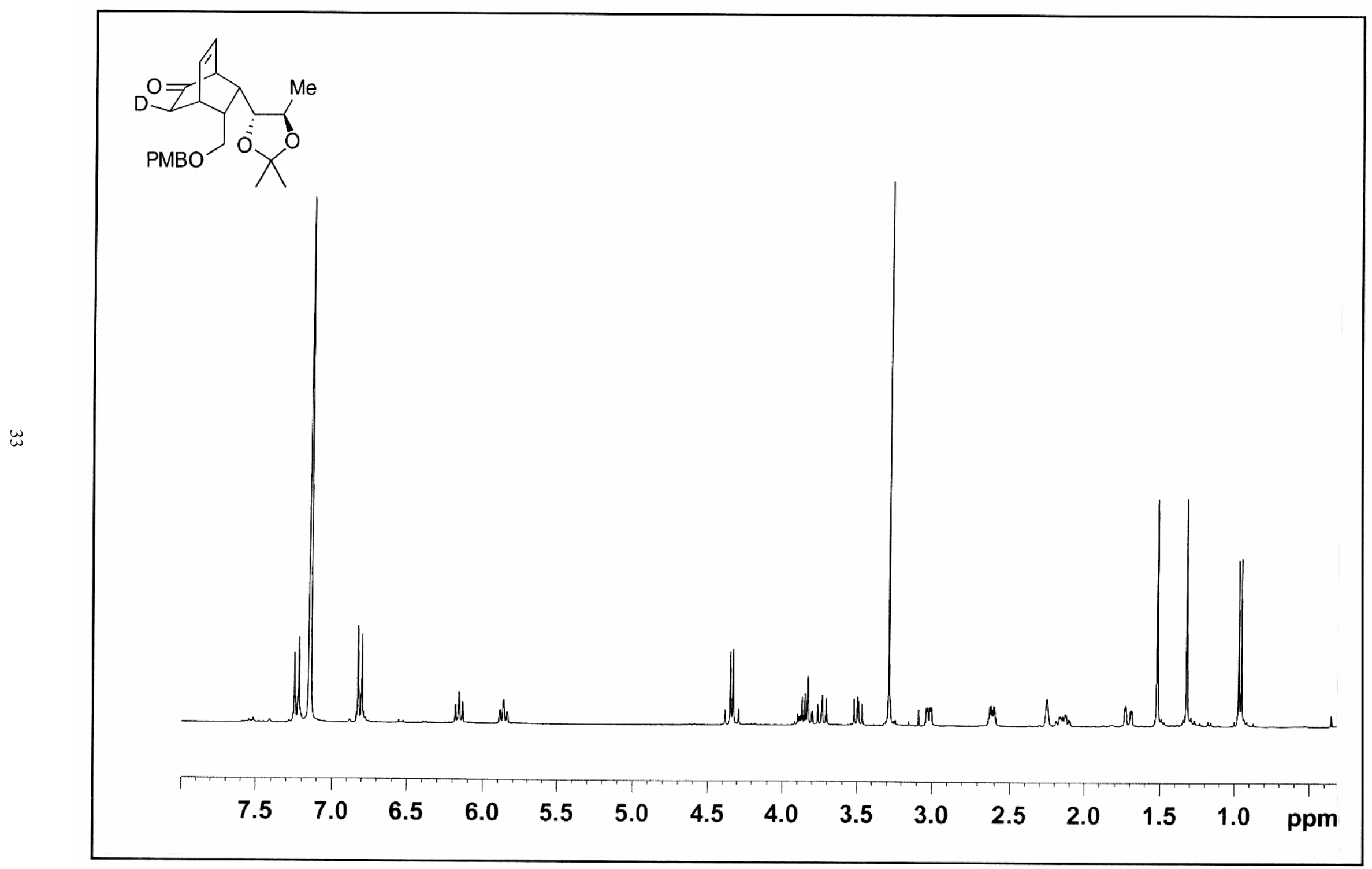

$300 \mathrm{MHz}{ }^{1} \mathrm{H}$ NMR of Compound $31\left(\mathrm{C}_{6} \mathrm{D}_{6}\right)$ 


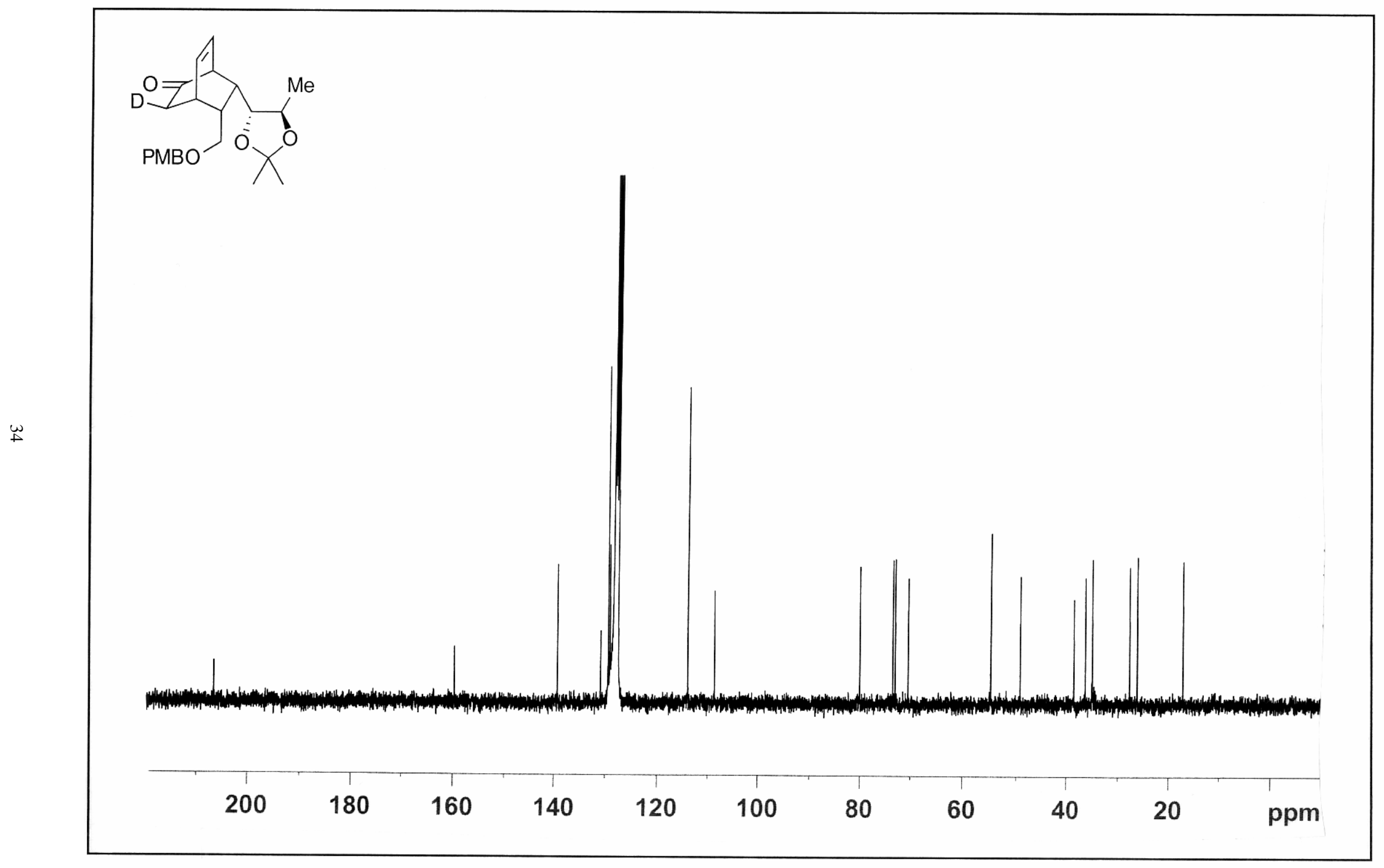

$75 \mathrm{MHz}{ }^{13} \mathrm{C}$ NMR of Compound $31\left(\mathrm{C}_{6} \mathrm{D}_{6}\right)$ 


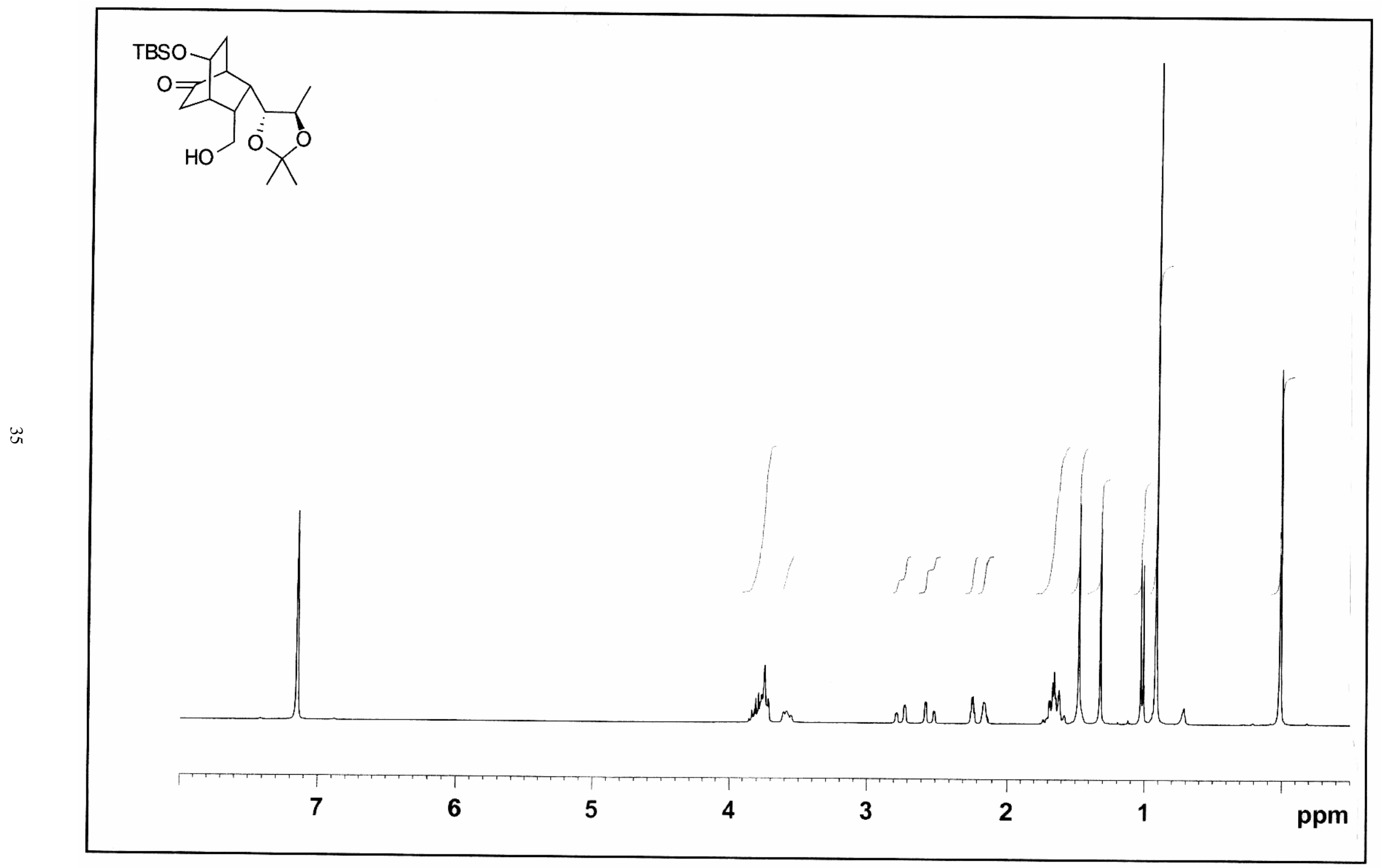

$300 \mathrm{MHz}{ }^{1} \mathrm{H}$ NMR of Compound 26c $\left(\mathrm{C}_{6} \mathrm{D}_{6}\right)$ 


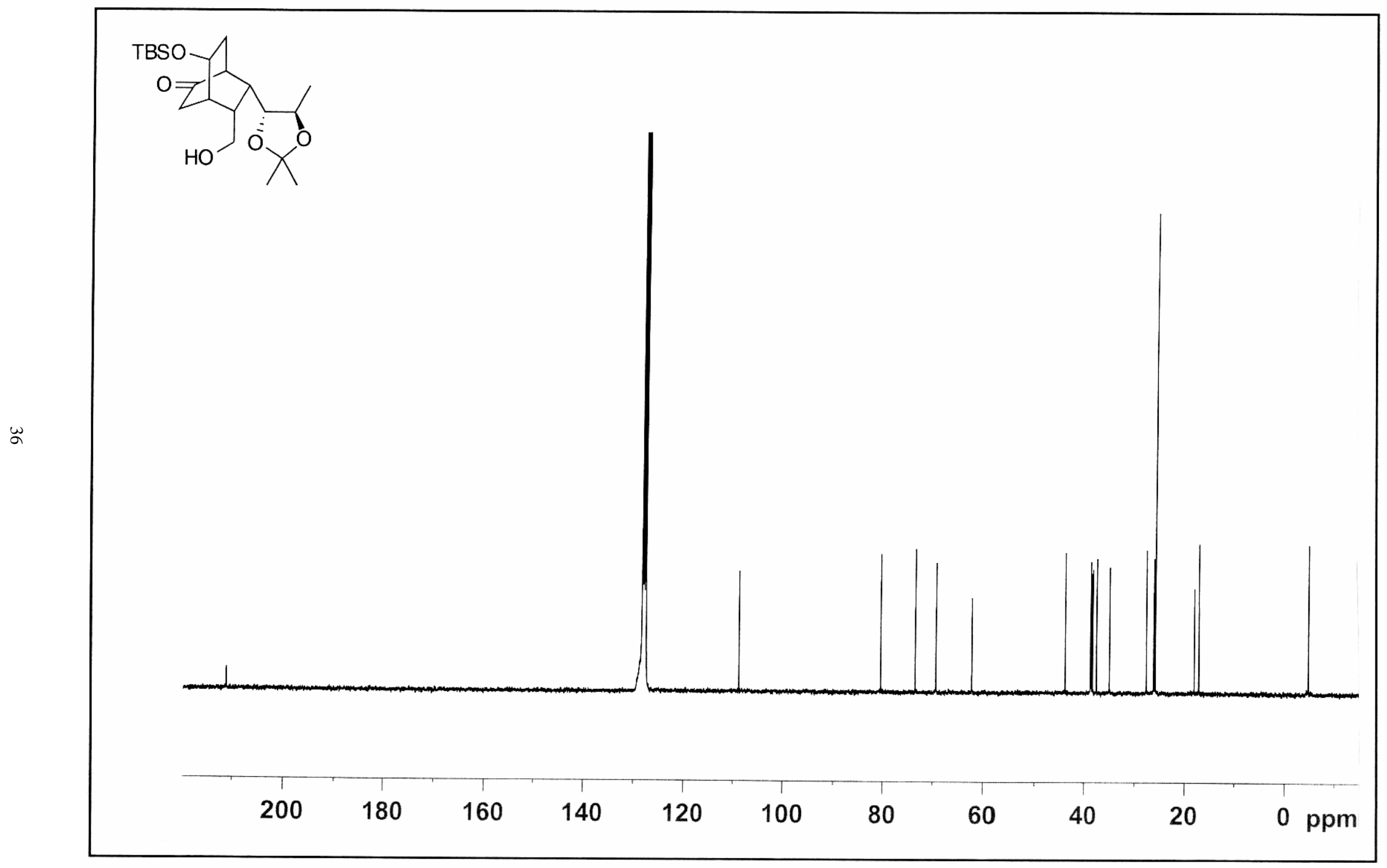

$75 \mathrm{MHz}{ }^{13} \mathrm{C}$ NMR of Compound 26c $\left(\mathrm{C}_{6} \mathrm{D}_{6}\right)$ 


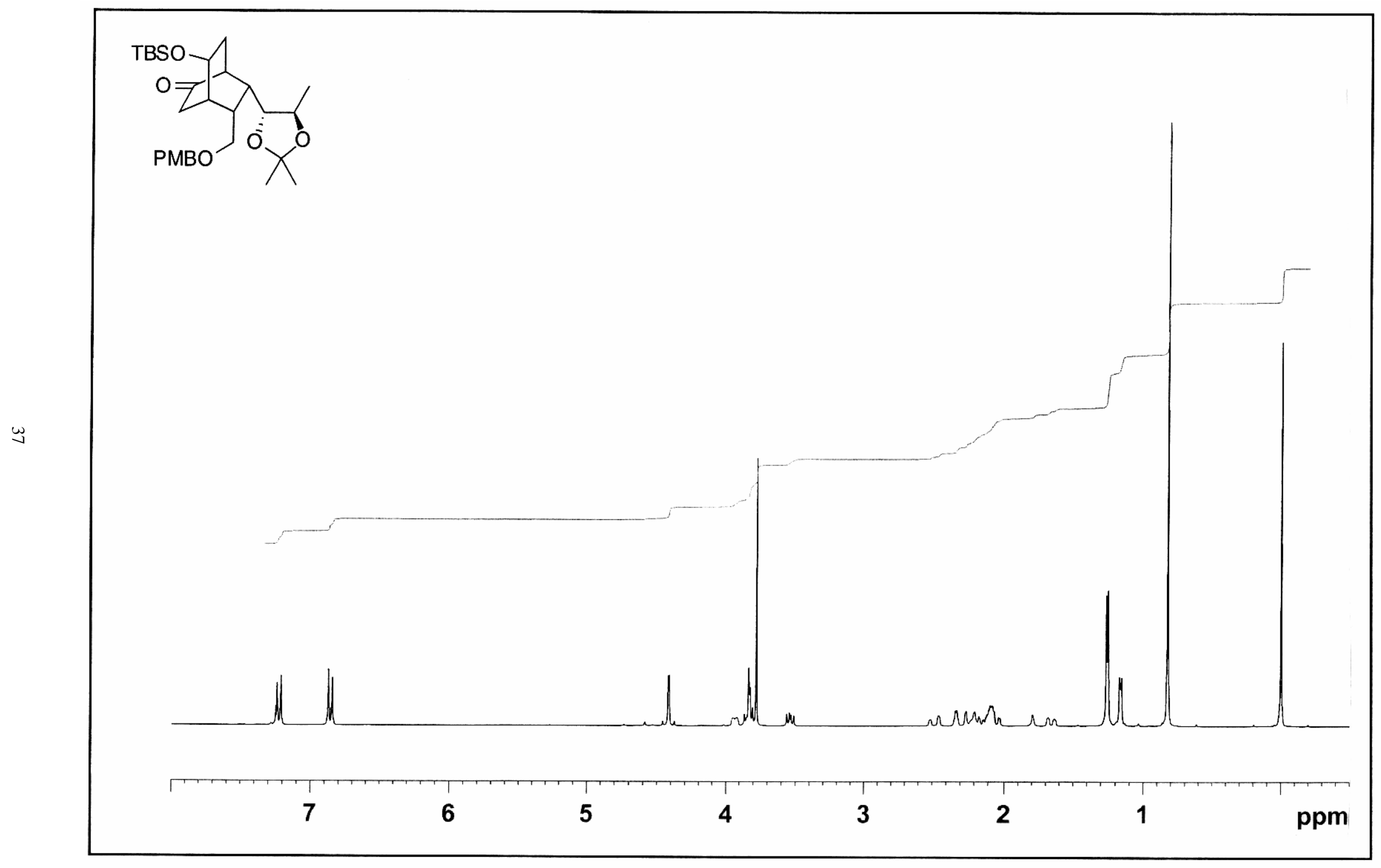

$300 \mathrm{MHz}{ }^{1} \mathrm{H}$ NMR of Compound $32\left(\mathrm{CDCl}_{3}\right)$ 


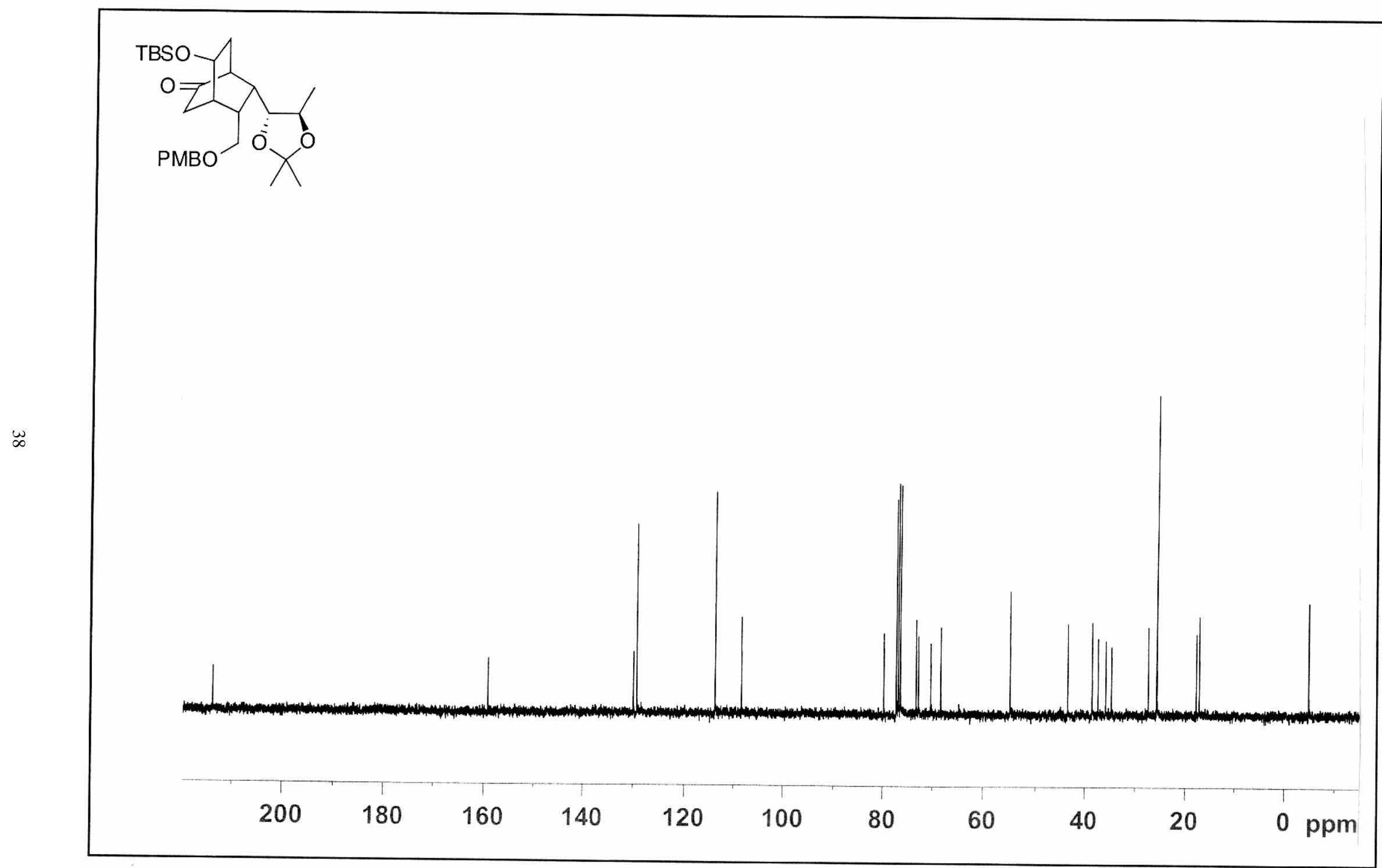

$75 \mathrm{MHz}{ }^{13} \mathrm{C}$ NMR of Compound $32\left(\mathrm{CDCl}_{3}\right)$ 


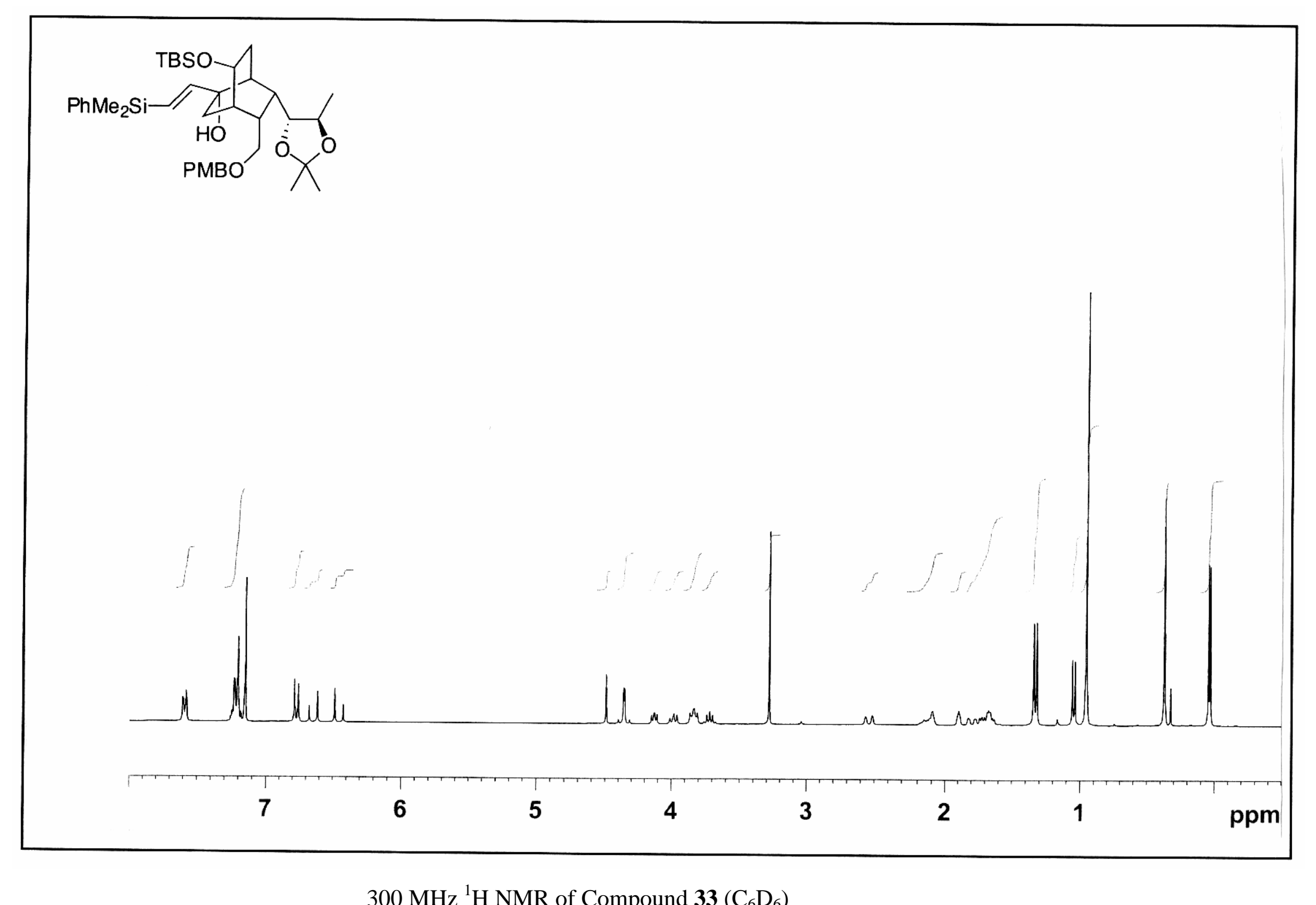




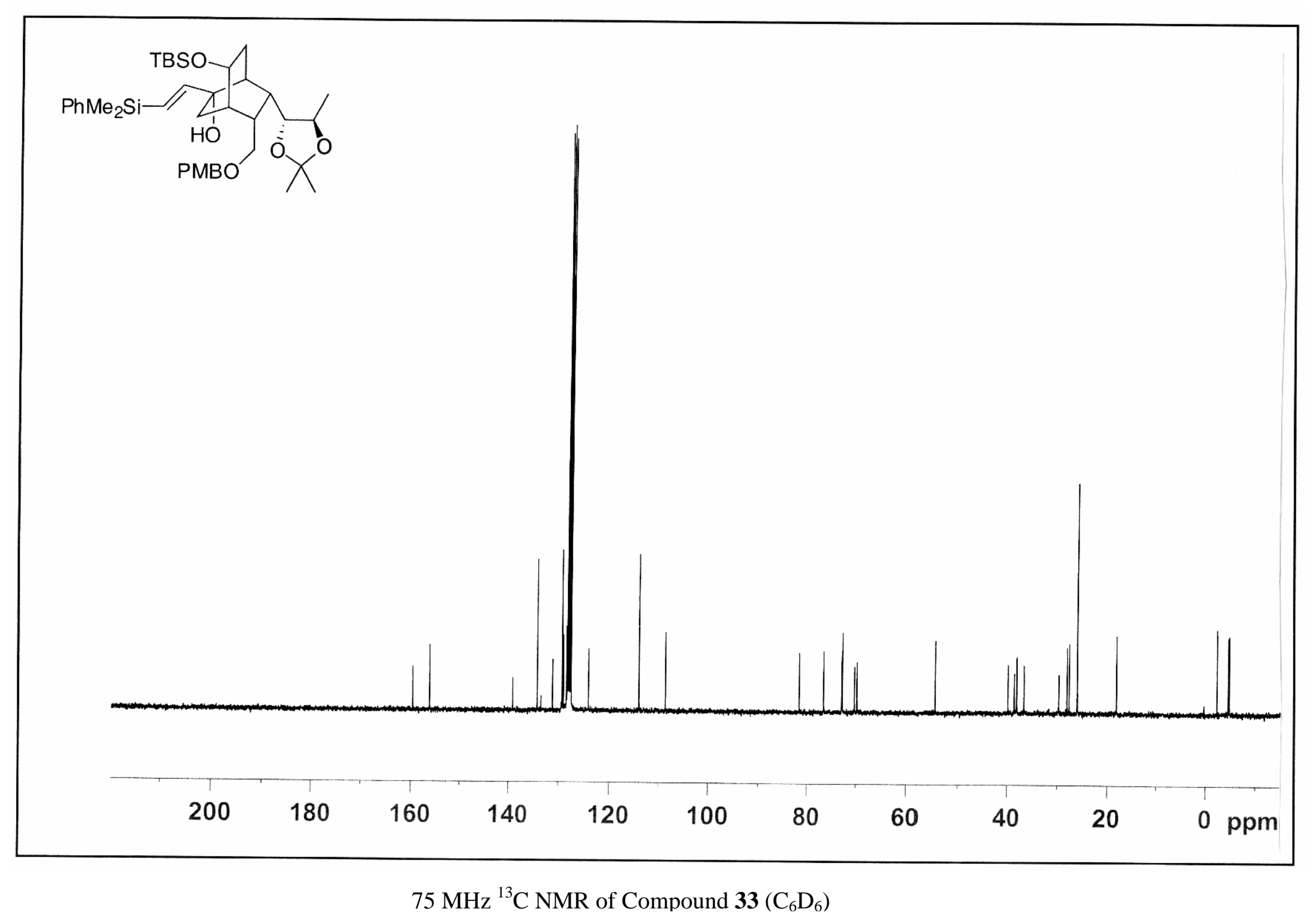




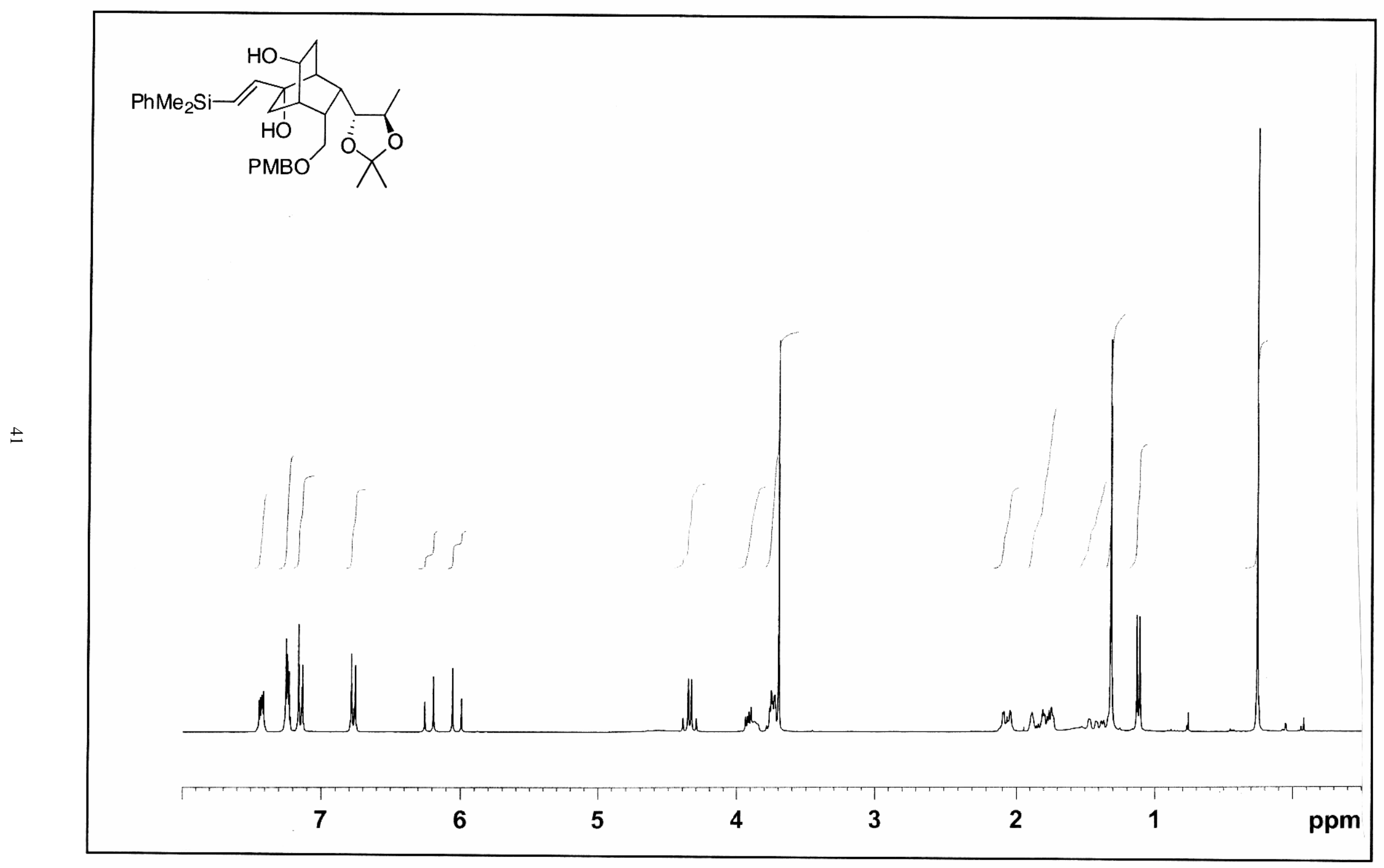

$300 \mathrm{MHz}{ }^{1} \mathrm{H}$ NMR of Compound 33a $\left(\mathrm{CDCl}_{3}\right)$ 


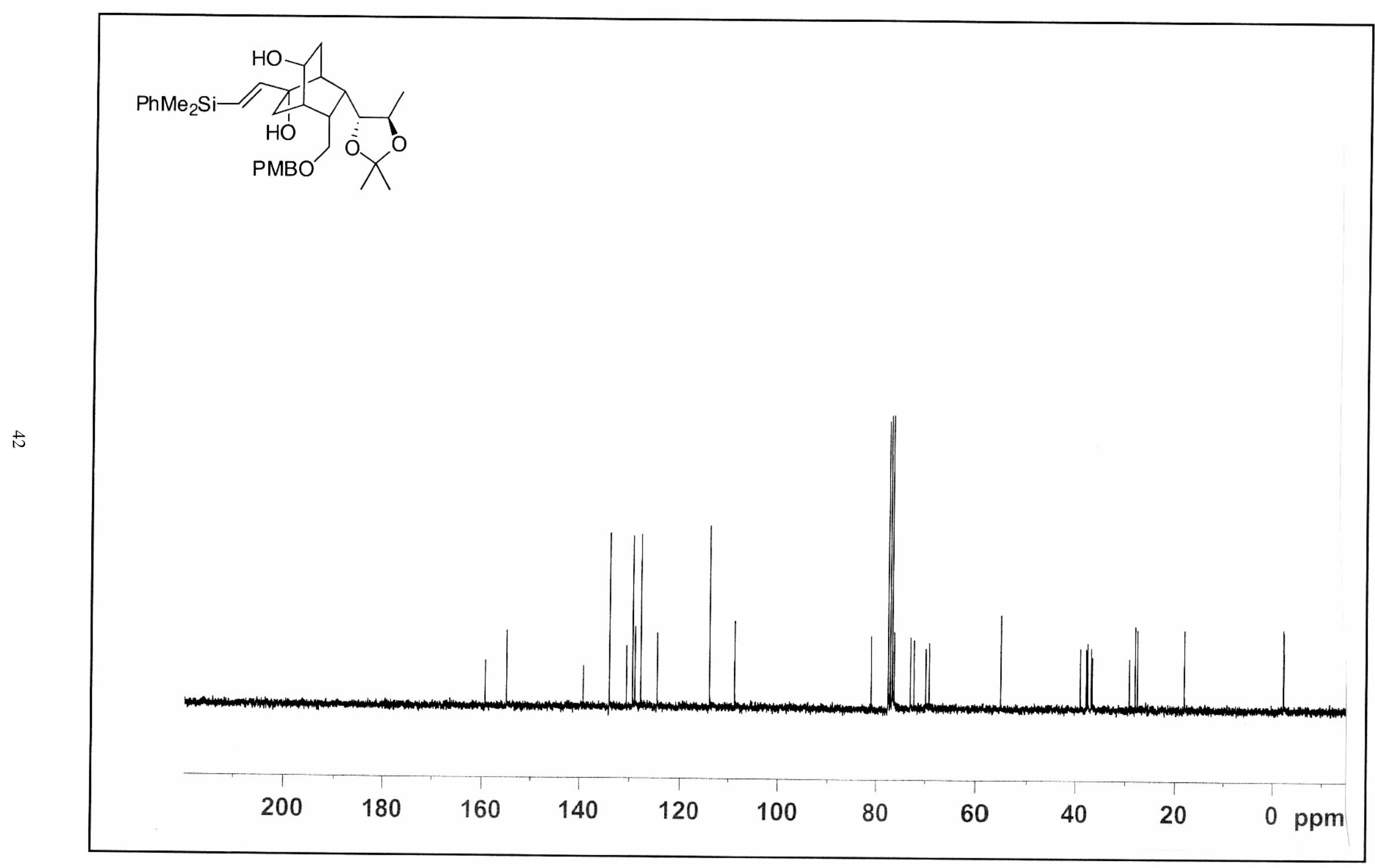

$75 \mathrm{MHz}{ }^{13} \mathrm{C}$ NMR of Compound 33a $\left(\mathrm{C}_{6} \mathrm{D}_{6}\right)$ 


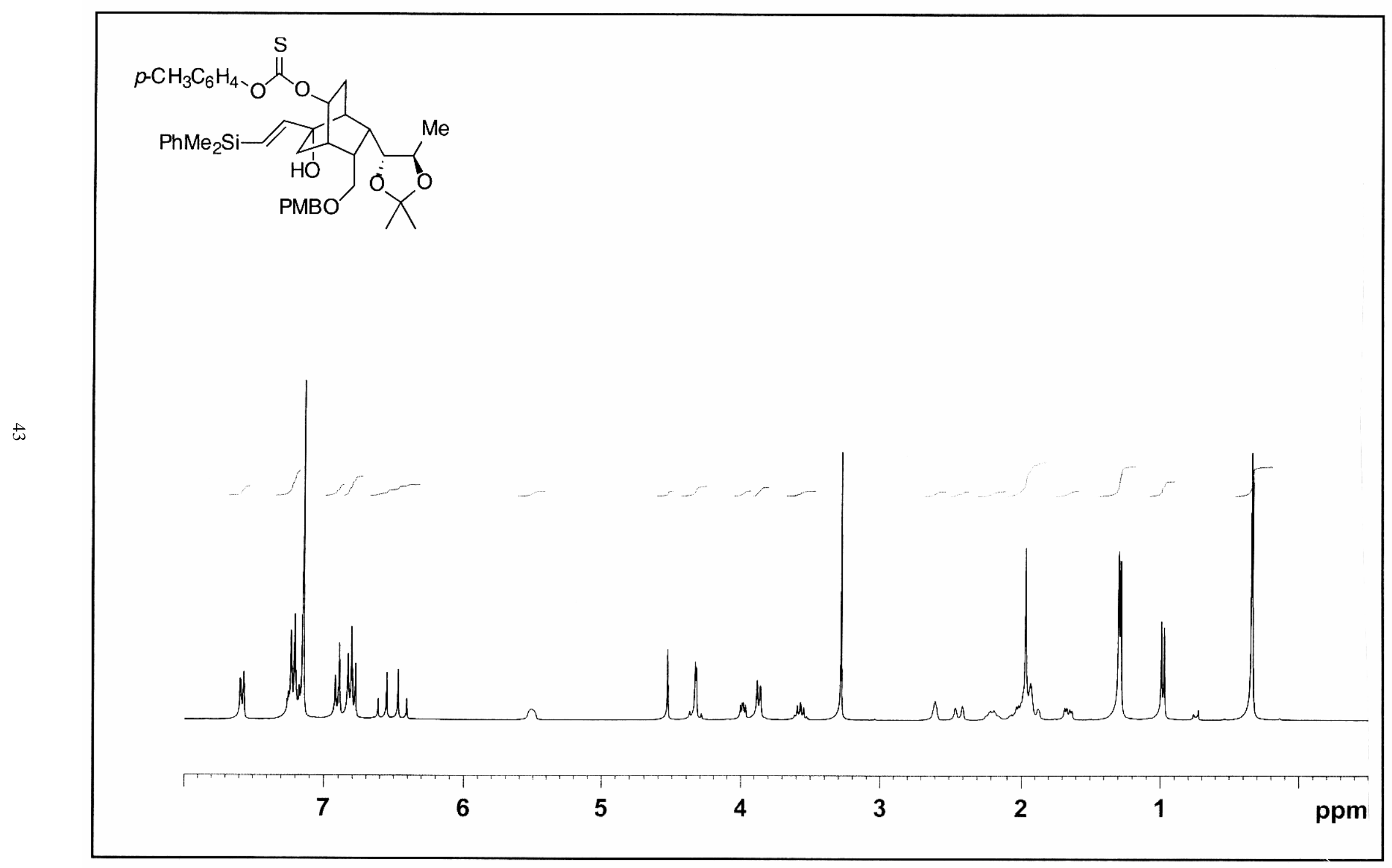

$300 \mathrm{MHz}{ }^{1} \mathrm{H}$ NMR of Compound 33b $\left(\mathrm{C}_{6} \mathrm{D}_{6}\right)$ 


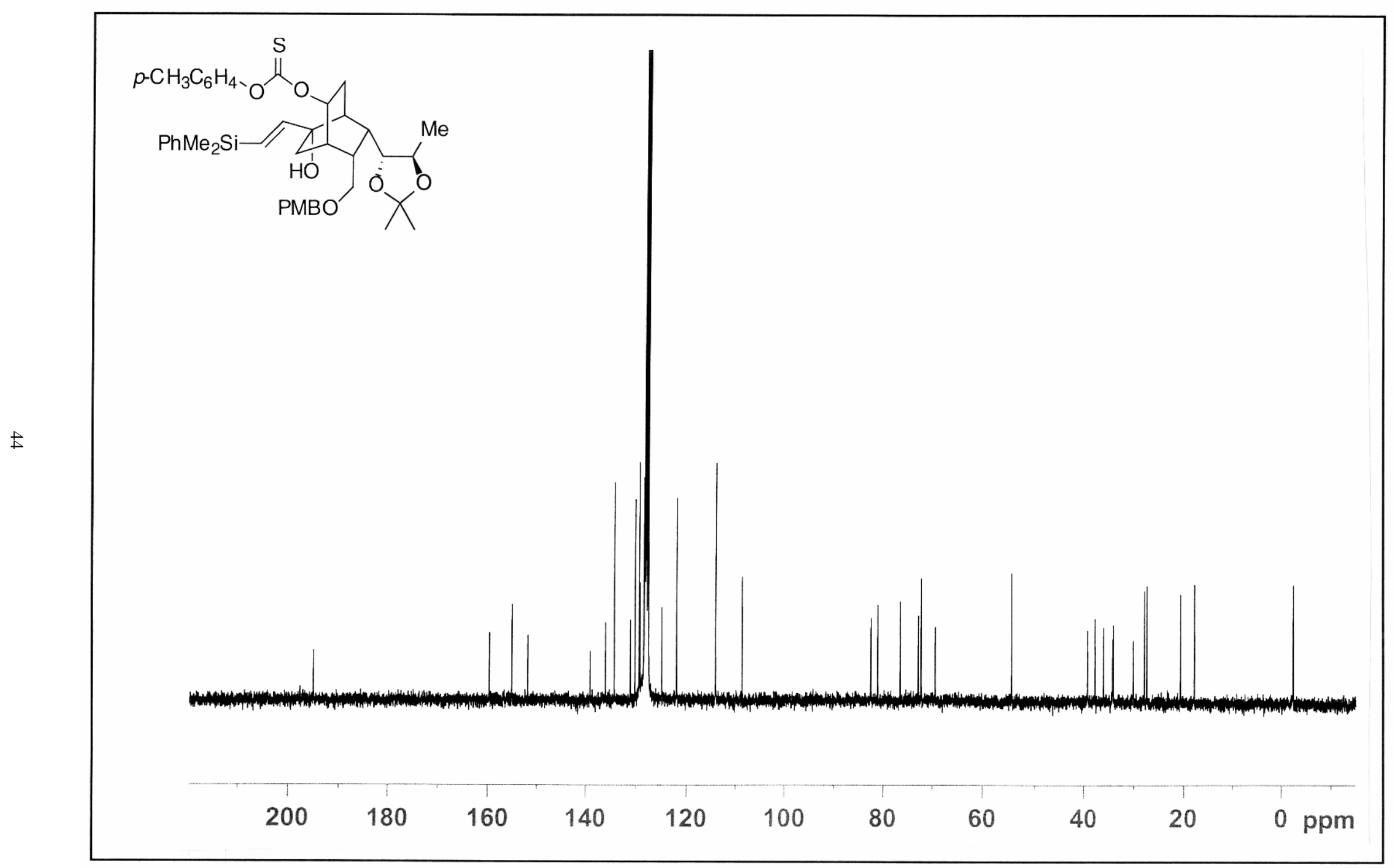

$75 \mathrm{MHz}{ }^{13} \mathrm{C}$ NMR of Compound 33b $\left(\mathrm{C}_{6} \mathrm{D}_{6}\right)$ 


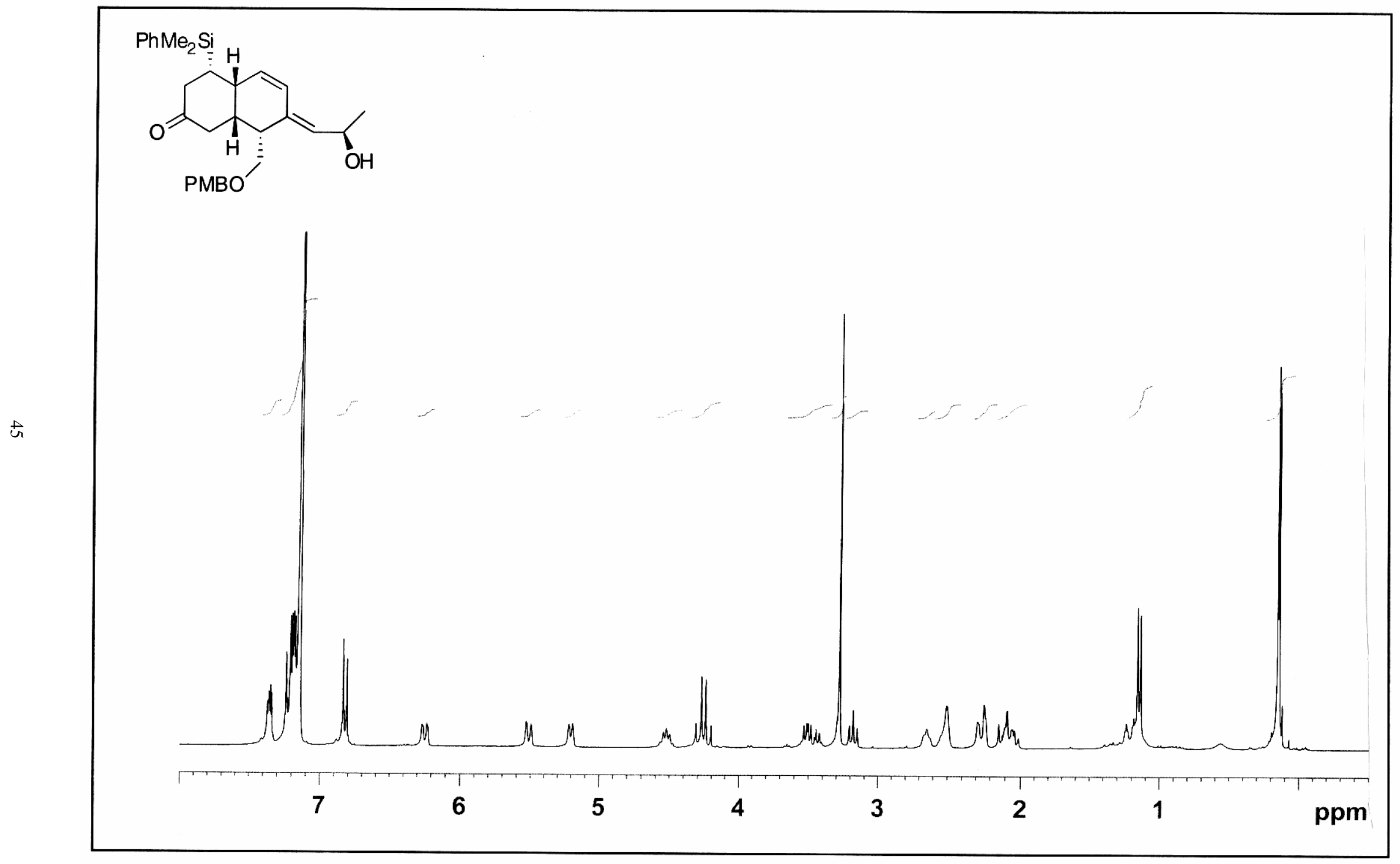

$300 \mathrm{MHz}{ }^{1} \mathrm{H}$ NMR of Compound $34\left(\mathrm{C}_{6} \mathrm{D}_{6}\right)$ 


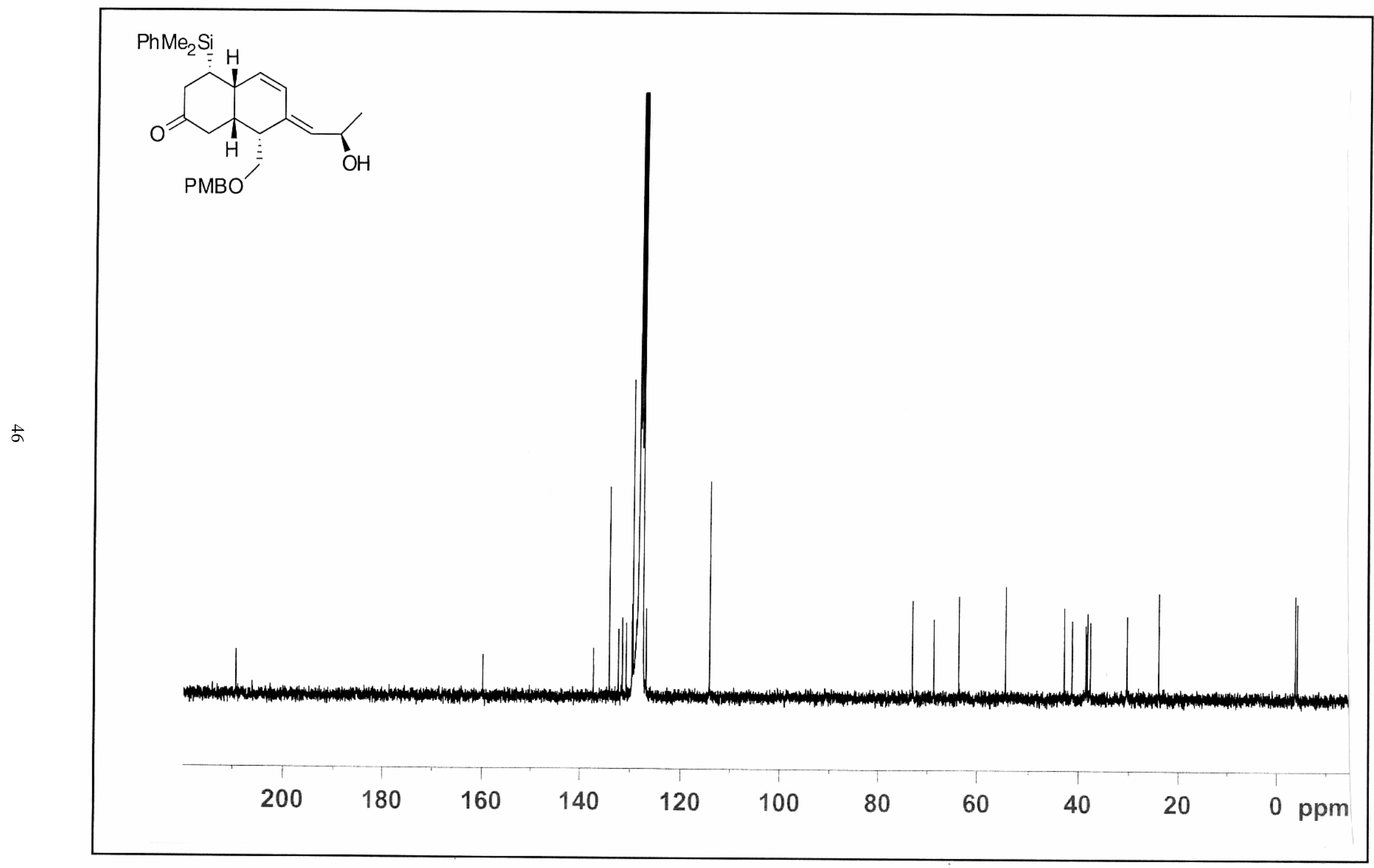

$75 \mathrm{MHz}{ }^{13} \mathrm{C}$ NMR of Compound $34\left(\mathrm{C}_{6} \mathrm{D}_{6}\right)$ 


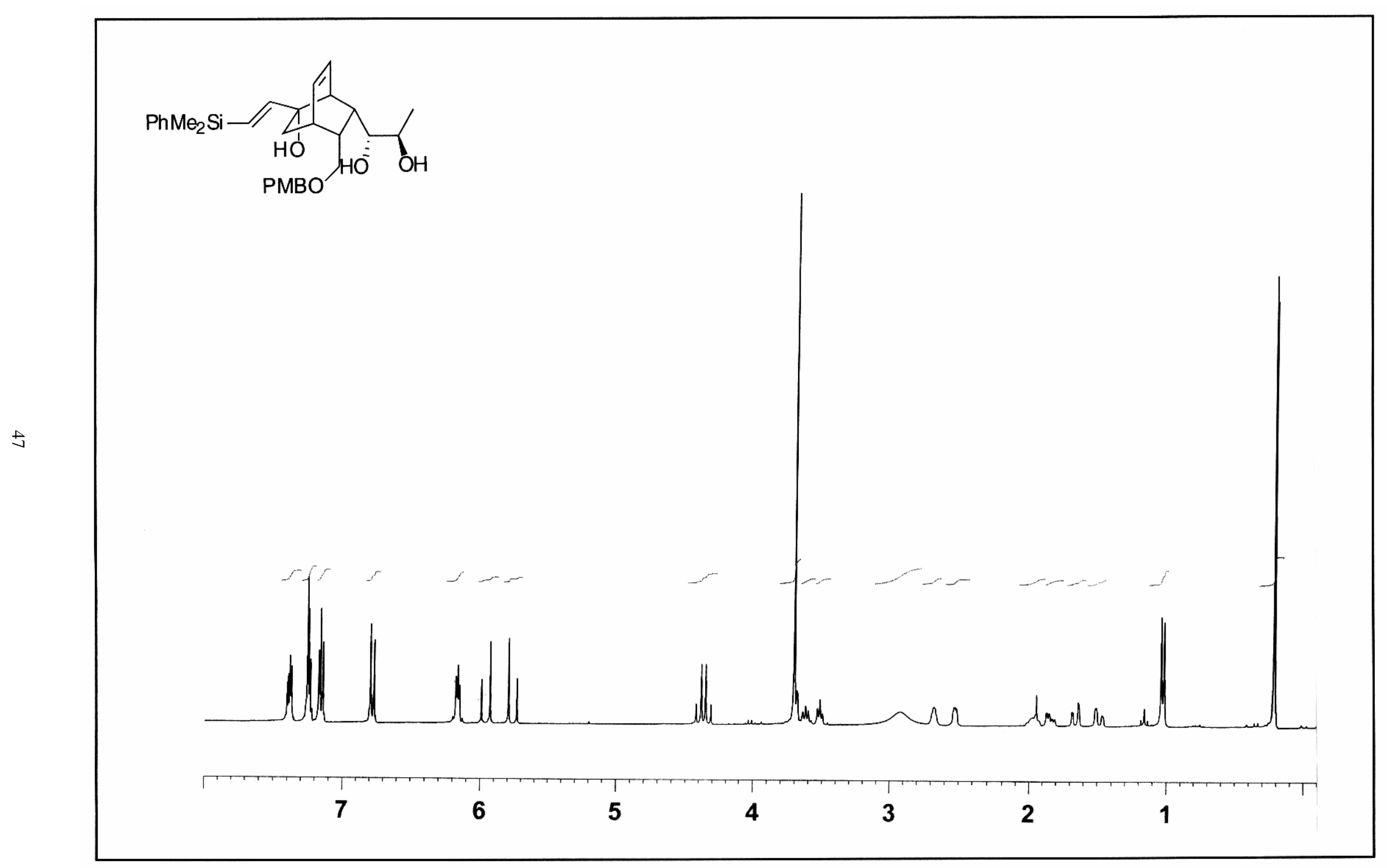

$300 \mathrm{MHz}{ }^{1} \mathrm{H}$ NMR of Compound 30a $\left(\mathrm{CDCl}_{3}\right)$ 


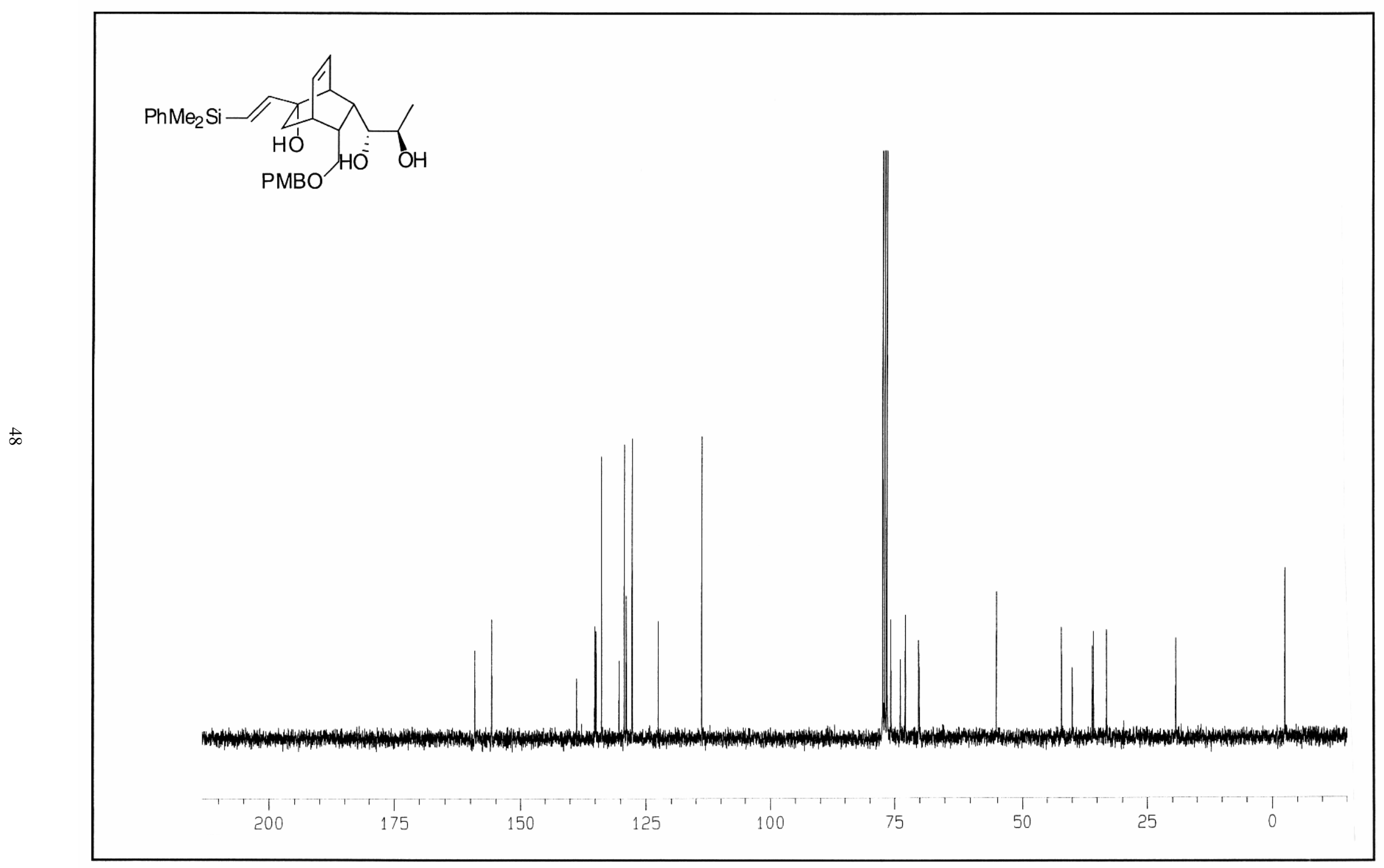

$75 \mathrm{MHz}{ }^{13} \mathrm{C}$ NMR of Compound 30a $\left(\mathrm{CDCl}_{3}\right)$ 


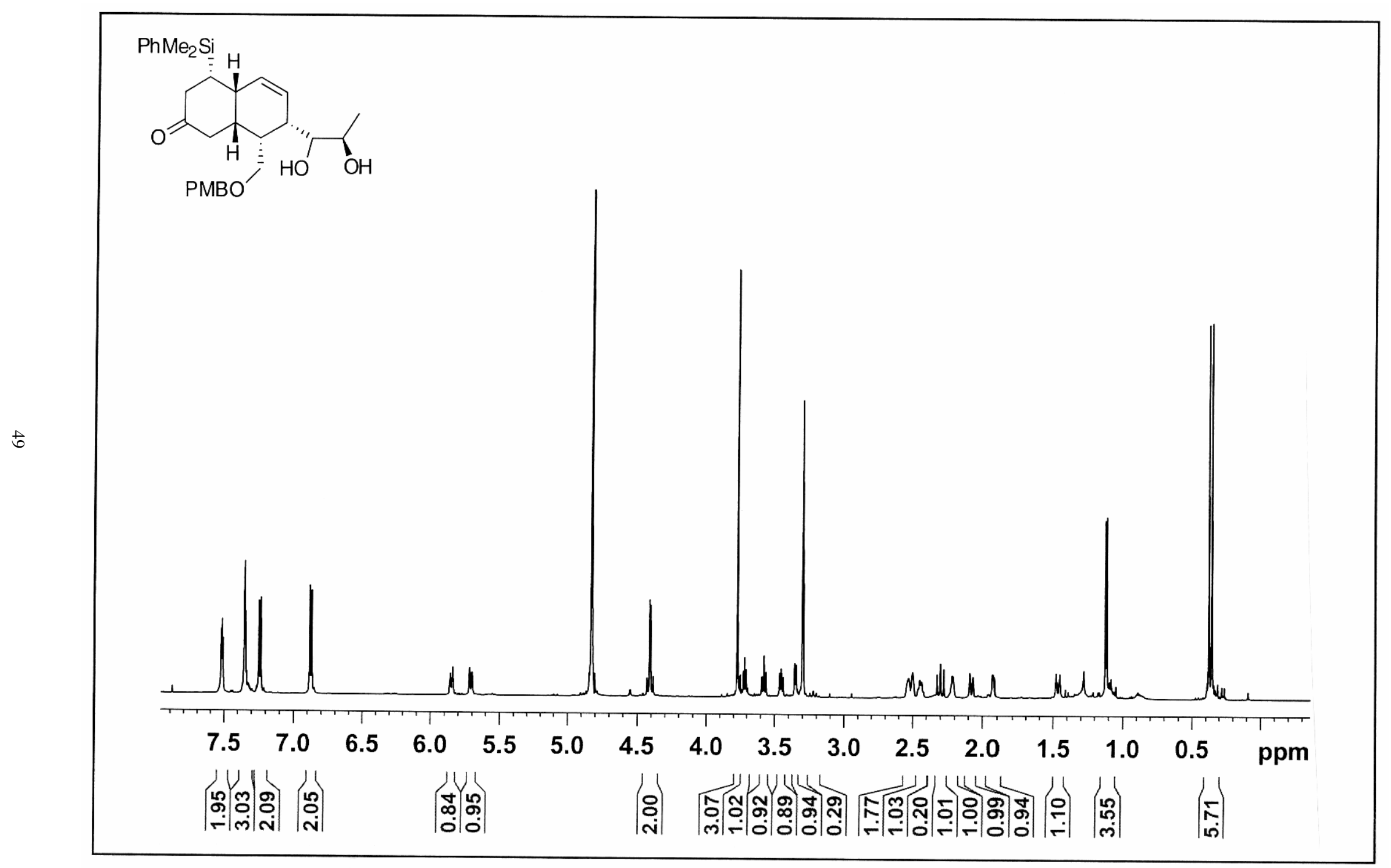

$600 \mathrm{MHz}{ }^{1} \mathrm{H}$ NMR of Compound $35\left(\mathrm{CD}_{3} \mathrm{OD}\right)$ 


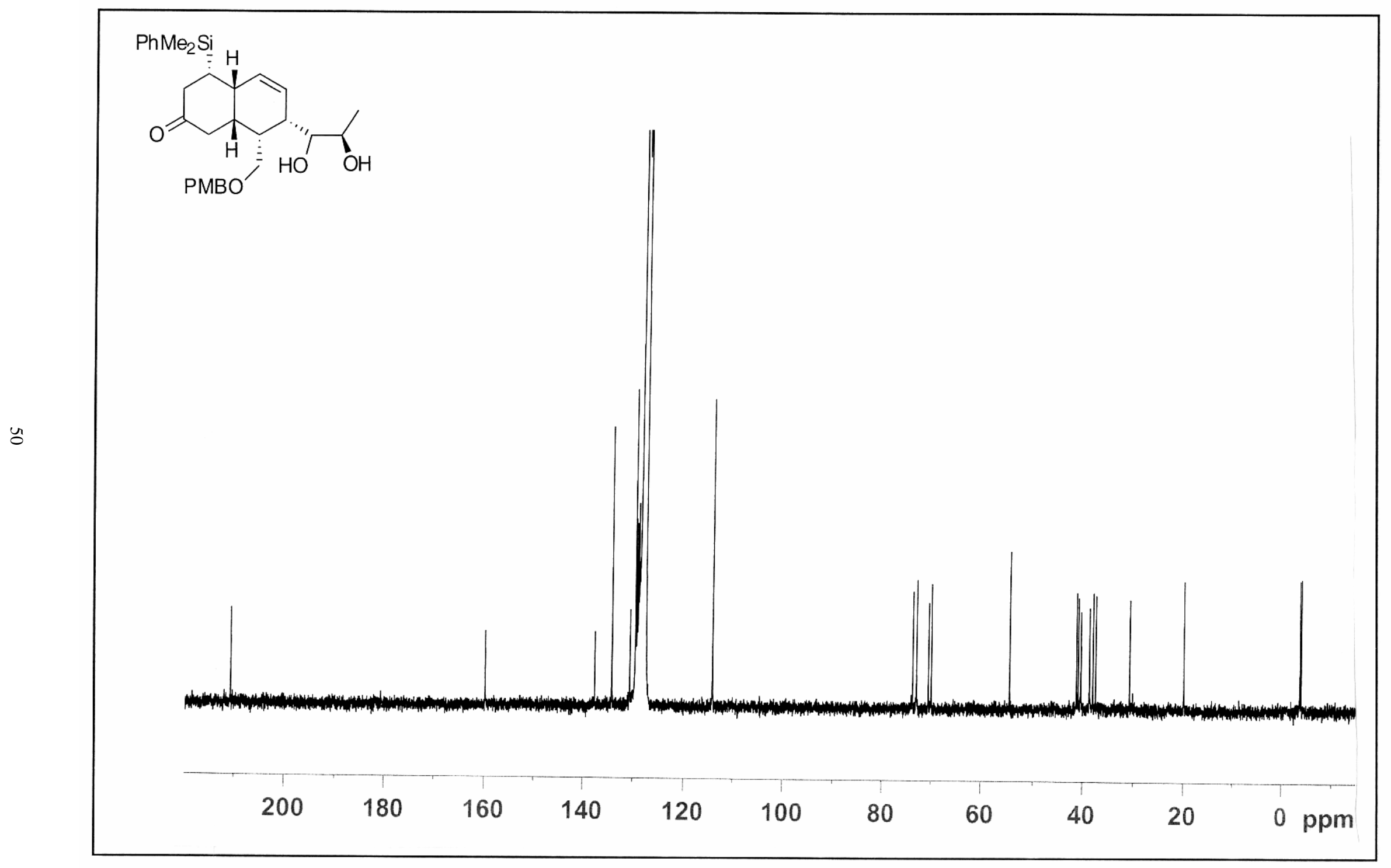

$75 \mathrm{MHz}{ }^{13} \mathrm{C}$ NMR of Compound $35\left(\mathrm{C}_{6} \mathrm{D}_{6}\right)$ 